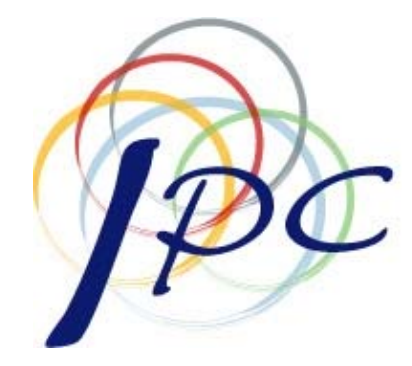

InTERnational Policy Center

Gerald R. Ford School of Public Policy University of Michigan

IPC Working Paper Series Number 84

Cross-Border Target Selection and Investor Protection Disparity

Yao Lu

April, 2009 


\title{
CROSS-BORDER TARGET SELECTION AND INVESTOR PROTECTION DISPARITY ${ }^{1}$
}

\author{
YAO LU \\ Stephen M. Ross School of Business \\ University of Michigan
}

Underperforming firms in emerging markets have little access to foreign capital is a well-documented but little understood phenomenon. I argue that this phenomenon is due to the gap in the strength of investor protection (IP) between capital exporting and importing countries. An acquirer from a strong-IP country values control premiums less than does a typical controlling shareholder in a weak-IP country. Thus, the acquirer is attracted to better performing companies that have the stronger incentives to practice better corporate governance and demand lower control premiums in acquisition prices. I examine how the passages of corporate governance reforms (CGRs) undertaken by either target or acquirer countries affect the target selection tendency of acquirers from 20 strong-IP countries in 21 weakIP countries. When a CGR in a target country narrows the IP gap, acquirers exhibit more willingness to pursue underperforming firms. Conversely, acquirers' tendency to cherry pick increases in response to their own home countries' CGRs, which increase the IP gap. These findings imply that weak IP prevents poorly performing local firms from gaining access to foreign capital and those CGRs in weak-IP countries help guide international capital flows to companies with more room to improve.

Keywords: Corporate Governance Reforms, Investor Protection, Cross-border Acquisitions, Target Selections, Private Benefits of Control, and Foreign Direct Investments

\footnotetext{
${ }^{1}$ This paper is based on a chapter of my doctoral dissertation at the University of Michigan. I am grateful to my thesis committee co-chairs, E. Han Kim and Jan Svejnar, and committee members, Vikramaditya Khanna, Katherine Terrell, and Linda Tesar. I also thank Laura Alfaro, Art Durnev, Francine Lafontaine, Erica Li, Jeffrey Smith, Jagadeesh Sivadasan, Dean Yang, Minyuan Zhao, and participants of Finance seminar, Economic Development and Transition Seminar, and Business Economics Seminar at University of Michigan Ross School of Business, and International Finance Section in NEUDC 2007 conference at Harvard University for their helpful commentsand suggestions, and Kai Petainen and Julian Atanassov for the advice on identifying data sources, and Joyce Buchanan for editing. All errors are my own. I acknowledge financial support from Mitsui Life Financial Research Center at the University of Michigan.
} 


\section{INTRODUCTION}

Although poorly performing firms tend to be in greater need for capital and have more room for improvement in productivity, those in emerging markets have little access to foreign capital or their technical and managerial know-how. Aitken and Harrison (1999) use panel data on Venezuelan plants and find that foreign equity participation is positively correlated with plants' pre-acquisition productivity. Sabirianova, Svejnar, and Terrell (2005) demonstrate a similar phenomenon with data on Eastern European firms. Leuz, Lins, and Warnock (2008) show that foreign investors invest less in poorly governed firms in countries with weak legal investor protection. Such cherry picking phenomena seem to be unique for emerging markets. They are seldom observed for foreign acquisitions in industrialized countries (e.g., Haskel, Pereira, and Slaughter, 2007). Additionally, for U.S. domestic acquisitions, underperforming firms are more likely to become targets (e.g., Maksimovic and Phillips, 2001) ${ }^{2}$.

This cherry picking phenomenon has attracted considerable attentions from the scholars and policy makers. It prevents underperforming local firms from gaining access to foreign investment, thereby limits the extent of corporate governance convergence and technology spill-over (e.g., Djankov and Hoekman, 2000).

One attribute of foreign investment in emerging markets is significant "disparity" in the strength of investor protection (IP) between acquirer and target countries. It is well documented that IP has important impacts on corporate governance, capital market development, and capital flows. For example, stronger legal protection of minority shareholders is associated with more developed stock markets (La Porta, Lopez-deSilanes, Shleifer, and Vishny, 1997); fewer private benefits of control (Dyck and Zingales, 2004; Nenova, 2003); a greater volume of M\&A activities (Rossi and Volpin, 2004); and more foreign capital inflows (e.g., Gelos and Wei, 2005; Alfaro, KalemliOzcan, and Volosovych, 2008).

\footnotetext{
${ }^{2}$ A similar phenomenon is also observed in block transactions. Bethel, Liebeskind, and Opler (1998) find that activist investors are more likely to purchase block shares in poorly performing corporations. Additionally, with data on U.S. domestic acquisitions, acquisitions of underperforming firms have been found to generate greater values for bidders, targets, and total synergistic gains (e.g., Lang, Stulz, and Walkling, 1989; Servaes, 1991; Andrade, Mitchell, and Stafford, 2001).
} 
In this paper, I explain the cherry picking phenomenon within a law and finance framework. I theoretically demonstrate that when the acquirer country has stronger IP regulations than does the target country, the acquirer tend to select well-performing firms.The data is consistent with this prediction. Furthermore, the evidence becomes stronger, when the IP gap increases. These results imply that the weak IP of host countries works as a barrier against local firms in a greater need for improvement from gaining access to foreign capital and technical and managerial know how.

Over the past decade, there has been a global trend toward stronger IP. Many countries have enacted corporate governance reforms (CGRs). I use the CGRs to perform difference-in-difference tests of how acquirers from 20 strong-IP countries change their target selection decisions in 21 weak-IP countries in response to the reforms undertaken by the target or the acquirer countries. The divergence in IP has a significant effect on cross-border acquisition target selection. Acquirers from strong-IP country diminish (raise) their tendency to cherry pick in weak-IP target countries, when the IP gap shrinks (increases) due to CGRs undertaken by the target (acquirer) countries. This empirical approach is similar to that of Branstetter, Fisman, and Foley (2006), which examines how intellectual property rights reforms affect technology transfer by multinational firms.

I start with a simple model assuming that a controlling shareholder derives two streams of benefits from the firm: (1) cash flow rights and (2) private benefits through control rights $^{3}$ (e.g., La Porta, Lopez-de-Silanes, Shleifer, and Vishny, 2002). When an acquisition takes place, both cash flow and control rights are transferred; hence, the transaction price includes the values of both rights. The value of cash flow rights is reflected in the value of traded assets. Control rights are priced as control premiums at the value of the private benefits of control (Dyck and Zingales, 2004).

Although firms in weak-IP countries, on average, have poor corporate governance, there are variations in the quality of governance between well- and poorlyperforming firms. Durnev and Kim (2005) show that when investment opportunities are more profitable, the controlling shareholders have less incentive to steal corporate resources because of the greater opportunity costs of forgoing investments. Thus, the

\footnotetext{
${ }^{3}$ Private benefits of control can be derived in various ways: tunneling companies' resources, paying abnormally high compensation, enjoying excessive perks, and so on.
} 
controlling shareholders of well performing firms may decide to consume fewer private benefits, making them more attractive targets to acquirers from strong-IP countries. While the values of such target companies (relative to their earnings power) are higher to reflect their strong governance, their controlling owners will demand lower control premiums when selling. Thus, they are more palatable to acquirers domiciled in countries with strong legal investor protection imposing tougher restrictions on the ability to consume private benefits. ${ }^{4}$

Distinguishing from existing studies on foreign investment with only regional data (e.g., studies on foreign investment in Korea (Kim, Sung, and Wei, 2008); in Venezuela (Aitken and Harrison, 1999)), which raise the concerns about the generalization of the results, I construct a sample including 20 strong-IP countries' crossborder acquisitions in 40 countries. The strength of IP is defined as the median of an IP index based on the Anti-self-dealing index of Djankov, La Porta, Lopez-de-Silanes, and Shleifer (2008) and the Law-and-Order index of International Country Risk (ICR). A Probit analysis shows that acquirers from strong-IP countries select well-performing firms only in weak-IP countries, but not in strong-IP countries.

I also investigate how changes in the disparity in IP between the acquirer and target countries affect cross-border acquisition target selection. This difference-indifference test is conducted employing the within country variation in IP generated by CGRs undertaken by target and acquirer countries. When the acquirer country has stronger IP than does the target country, a CGR undertaken by the target country may narrow the IP gap. I first compare the type of firms being targeted before and after the CGR. To control for time effects occurring around the CGR, I treat the acquisitions in countries not undertaking CGRs in the same year as the control group. The difference in the difference in the type of firms being targeted before and after the CGR year in CGR countries (treatment group) and non-CGR countries (control group) can serve to identify the impact of a CGR undertaken by the target country. I also examine how acquirers from strong-IP countries change their foreign target selection in response to their own home countries' CGRs. Again, the type of firms being targeted is compared before and after a

\footnotetext{
${ }^{4}$ Dyck and Zingales (2004) empirically show that acquirers from stronger-IP countries tend to pay lower control premiums in an acquisition transaction.
} 
CGR is undertaken in the acquirer country. To control for the time effects, the acquisitions by the acquirers whose home countries do not undertake CGRs in the same year is treated to be the control group.

For this difference-indifference test, I use data on 17 strong-IP countries' crossborder acquisitions in 21 weak-IP countries. I find that acquirers from strong-IP countries exhibit more willingness to target underperforming firms after target countries undertake CGRs, which narrow the IP gaps. Conversely, these acquirers tend to pursue even betterperforming t firms after their home countries undertake CGRs, which enlarge the IP gaps. The results are robust to the endogenous timing of reforms and the potential impact of CGRs on the performance of all firms in the same country, year, and industry. Overall, consistent with my theoretical predictions, when the IP disparity changes due to CGRs, whether undertaken by the target or acquirer country, acquirers change their cherry picking tendency in the same direction as predicted.

This study makes contributions on several fronts. In the international capital flow literature, previous studies have paid considerable attentions to how legal environments affect international capital flows across countries. For example, Gelos and Wei (2005) and Alfaro, Ozcan, and Volosovych (2008) demonstrate that weak legal environments can be a reason for insufficient flow of capital from rich to poor countries; namely the "Lucas Paradox." In this paper, I go beyond the country difference and provide evidence on how the legal environment affects international capital flows at the firm level.

Kim, Sung, and Wei (2008), Ferreira and Matos (2008) and Leuz, Lins, and Warnock (2008) provide empirical evidence linking legal environments with firm-level international investment target selection. This paper differentiates from those studies in three important aspects. First, this paper provides a theoretical framework to analyze how legal environments affect target selection decisions. Second, unlike these studies which focus on either home or host countries' legal environment, this paper covers the impact of legal environments of both capital exporting and importing countries and demonstrate the importance in the disparity in the strength in IP between countries. Finally, the sample used in this study covers broader range of capital importing and exporting countries, instead of single country, rendering the results more general. 
Finally, following Durnev and Kim (2005), this study combines the law and finance paradigm with the corporate finance approach to provide insights into how IP affects cross-border acquisition decisions. The results illustrate that weak local IP prevents the cross-border acquisition market from reallocating corporate resources to higher-valued uses for local firms with most room for improvement.

The paper proceeds as follows. A simple theoretical model is presented in Section II. Section III relates the likelihood of being a target to firm performance and the IP gap between the acquirer and target countries. Section IV investigates how changes in IP gap generated by CGRs affect the type of firms being targeted. Section $\mathrm{V}$ provides a summary.

\section{THEORETICAL FRAMEWORK}

To develop hypotheses, I consider an acquisition of a firm in which the controlling shareholder does not completely own the firm. This makes the value of control rights relevant for acquisition decisions. For simplicity, I focus only on firm-level heterogeneity in corporate governance of target firms, treating corporate governance of acquirers from a given country identical. I allow for asymmetry of information between the controlling shareholder and minority shareholders. This information asymmetry can be reduced by better disclosure regulations and corporate governance. However, I assume no information asymmetry between acquirers and targets. In practice, bidders tend to spend considerable resources in due diligence prior to acquiring a firm in their attempts to narrow the information disparity between acquirers and eventual targets.

The controlling shareholder derives two streams of benefits from the firm: cash flow rights and the private benefits generated by control rights. When an acquisition takes place, both cash flow and control rights are transferred from the controlling shareholder of the target to the acquirer. Hence, the value of cash flow and control rights would be included in the price of a transaction. The value of cash flow rights reflects the value of traded assets. Control rights are priced as control premiums equal to the value of the private benefits the incumbent controlling shareholder consumes before the acquisition (Dyck and Zingales, 2004). After the acquisition, private benefits the acquiring firm's 
controlling shareholder can consume is limited by the strength of IP of the acquirer country.

The setting is similar to those of La Porta et al. (2002) and Durnev and Kim (2005). The controlling shareholder has $\alpha$ fraction of a firm's outstanding shares, and the firm's profitability is measured by $\pi$ representing the gross return per unit of investment. The controlling shareholder diverts $d$ percent of $\pi$ for private benefits and leaves the rest in the firm. The cost of diversion is $(1 / 2) c(\pi d)^{2} . c>0$ is the cost of diversion generated by legal IP regulations. A higher $c$ indicates stronger IP. The cost of diversion is convex in the amount diverted, a standard assumption made by previous authors (e.g., Johnson, Boone, Breach, and Friedman, 2000; La Porta et al., 2002; Shleifer and Wolfenzon, 2002; Doidge, Karolyi, and Stulz, 2004; and Durnev and Kim, 2005). The benefits that the controlling shareholder derives from a firm consist of the value of cash flow rights after the diversion and the value of diversion net of diversion costs: $\alpha(1-d) \pi+d \pi-(1 / 2) c(\pi d)^{2}$. Thus, the controlling shareholder chooses $d$ to maximize:

$$
\operatorname{Max} \alpha \pi+d(1-\alpha) \pi-(1 / 2) c(\pi d)^{2}
$$

Where the sum of the second and third term represents her net private benefits of control, denoted as $P B$. Differentiating (1) with respect to $d$ and setting it equal to zero, the controlling shareholder's optimal level of diversion is: ${ }^{5}$

$$
d^{*}=(1-\alpha) /(\pi c)
$$

Differentiating (2) with respect to $c$ and $\pi$, we obtain:

$$
\begin{aligned}
& \partial d^{*} / \partial \mathrm{c}=-(1-\alpha) /\left(\pi c^{2}\right)<0 \\
& \partial d^{*} / \partial \pi=-(1-\alpha) /\left(\pi^{2} \mathrm{c}\right)<0
\end{aligned}
$$

The inequality in (3a) suggests that a controlling shareholder selects better corporate governance (i.e., diverts less), when a firm is located in a stronger IP country (La Porta et al., 2002). In a strong-IP country, strict and effective IP regulations make tunneling and stealing more difficult and costly for the controlling shareholder.

The inequality in (3b) suggests that controlling shareholders of firms with more profitable investment opportunities steal less from the firm (Durnev and Kim, 2005). Stealing reduces money that can be invested in projects. For firms with profitable investment opportunities, more stealing results in rejecting in more positive NPV projects,

\footnotetext{
${ }^{5}$ Since the controlling shareholder cannot steal more than $100 \%$ of the firm, it is impossible to have $d^{*} \geq 1$.
} 
reducing the benefits from cash flow rights for the controlling shareholder. In contrast, for firms with fewer positive NPV projects, stealing does less harm to the cash flow rights. Therefore, after trading off these benefits and costs, controlling shareholders of firms with more profitable investment opportunities will steal less from the firm (i.e., take less private benefits).

Let $c_{A}$ and $c_{T}$ represent the strength of IP of the acquirer and target country, respectively. $P B_{A}{ }^{*}$ and $P B_{T}{ }^{*}$ represent the optimal level of private benefits taken by the acquirer's controlling shareholder from the target after the acquisition and by the target's controlling shareholder before the acquisition, respectively. ${ }^{6}$ When the acquirer purchases $\alpha$ percent of target shares, the sum of $\alpha \pi$ and $P B_{T}{ }^{*}$ is equal to the reservation price of the incumbent controlling shareholder (Barclay and Holderness, 1989; Dyck and Zingales, 2004). Thus, the rate of return that the acquirer's controlling shareholder can obtain from the acquisition is defined as:

$$
R=\left(\left(\left(\alpha \pi+P B^{*}\right)-\left(\alpha \pi+P B_{T}^{*}\right)\right) /\left(\alpha \pi+P B_{T}^{*}\right)\right)+G,
$$

where $G$ is the operating synergies generated by the acquisition. Equation (4) shows that when $G=0$ and $c_{A}>c_{T}, R<0$, implying that firms in strong-IP countries will acquire firms in weak-IP countries only when the acquisition generates sufficient operating synergistic gains to offset the difference in private benefits.

To focus on the effect of a gap in IP, I consider only the gains arising from the acquirer's specialized resources that are unrelated to target's pre-acquisition $\pi{ }^{7}$ Examples include a foreign acquirer launching a new project with a technology unavailable to local firms or manufacturing goods using processes inaccessible to local firms. Combining the new technology or process with resources unique to the target country, such as natural resources or cheap labor, may generate operating synergies to the acquirer.

Equation (4) also raises the possibility that $R>0$ even when $G=0$ if $c_{A}<c_{T}$, which means IP is stronger in the target country than in the acquirer country. In such a case, $P B_{A}^{*}$ cannot exceed $P B_{T}^{*}$, because after the acquisition, the target firm still is

\footnotetext{
${ }^{6} \mathrm{~PB}_{\mathrm{A}}{ }^{*}$ and $\mathrm{PB}_{\mathrm{T}}{ }^{*}$ can be obtained by plugging $d_{A}{ }^{*}$ and $d_{T}{ }^{*}$ into $d(1-\alpha) \pi-(1 / 2) c(\pi d)^{2}$, respectively.

${ }^{7}$ The gains may also arise from target's specialized resources. An example would be under utilization of target's resources that can be redeployed to higher-valued uses under a stronger management. Such sources of synergistic gains can also be obtained by domestic acquisitions. Because the focus of the paper is crossborder acquisitions, I ignore such possibilities to examine how synergistic gains unique to cross-border acquisitions affect target selection.
} 
subject to the stronger regulations of the target country. Thus, a more precise definition of the rate of return from an acquisition is:

$$
R=\left(\operatorname{Min}\left(\left(P B_{A}^{*}-P B^{*}{ }_{T}\right), 0\right) /\left(\alpha \pi+P B^{*}\right)\right)+G,
$$

Substituting $d^{*}$ into $P B_{A}{ }^{*}$ and $P B_{T}{ }^{*}$ and differentiating $R$ with respect to $\pi$ yields: ${ }^{8}$

$$
\begin{aligned}
& \partial R / \partial \pi>0, \text { if } c_{A}>c_{T} \\
& \partial R / \partial \pi=0, \text { if } c_{A}<c_{T}
\end{aligned}
$$

The inequality in (6a) implies that when the acquirer country has stronger IP than does the target country, the return from a cross-border acquisition is higher when the target has more profitable investment opportunities.

Prediction 1: Other things being equal, when the acquirer country has stronger IP than does the target country, the acquirer tends to select well-performing target firms.

The intuition is that, other things being equal, a controlling shareholder consumes fewer private benefits of control when the firm is subject to stronger IP. As a result, the gap in IP between the acquirer and target countries causes disagreement on the value of control rights. ${ }^{9}$ Within a given legal environment, well-performing firms divert less (i.e., condition (3b)), making $P B^{*}$ smaller relative to the cash flow rights. As a result, a wellperforming firm is more attractive to an acquirer from a strong-IP country. ${ }^{10}$

Differentiating (6a) with respect to $c_{A}$ and $c_{T}$ shows that, if $c_{A}>c_{T}$, then ${ }^{11}$

$$
\begin{aligned}
& \partial^{2} R / \partial \pi \partial c_{T}<0 \\
& \partial^{2} R / \partial \pi \partial c_{A}>0
\end{aligned}
$$

The inequalities in (7a) and (7b) show that, other things being equal, when the acquirer country has stronger IP than does the target country, the tendency of an acquirer to target well-performing firms decreases as the IP of the target country gets stronger; conversely, this tendency increases as the IP of the acquirer country gets stronger.

\footnotetext{
$\left.{ }^{8} \partial \mathrm{R} / \partial \pi=-\left(\left((1-\alpha)^{2} / 2 \mathrm{c}_{\mathrm{A}^{-}}(1-\alpha)^{2} / 2 \mathrm{c}_{\mathrm{T}}\right)\right) \alpha\right) /\left(\alpha \pi+(1-\alpha)^{2} / 2 \mathrm{c}_{\mathrm{T}}\right)^{2}=\left((1-\alpha)^{2}\left(1 / 2 \mathrm{c}_{\mathrm{T}}-1 / 2 \mathrm{c}_{\mathrm{A}}\right) \alpha\right) /\left(\alpha \pi+(1-\alpha)^{2} / 2 \mathrm{c}_{\mathrm{T}}\right)^{2}$.

${ }^{9} \mathrm{After}$ an acquisition, although foreign acquirers from strong-IP countries are operating in countries with weak IP, they are still subject to their home countries' regulations.

${ }^{10}$ When the acquirer country has weaker IP than the target country, equation (6b) shows that the gap in IP does not affect $P B$ and, hence, the acquirer will be indifferent about the pre-acquisition performance of the target firm.

${ }^{11} \partial 2 \mathrm{R} / \partial \pi \partial \mathrm{C}_{\mathrm{A}}=\left(\left(1 / 2 \mathrm{C}_{\mathrm{A}}^{2}\right) \alpha(1-\alpha)^{2}\right) /\left(\alpha \pi+(1-\alpha)^{2} / 2 \mathrm{C}_{\mathrm{T}}\right)^{2} ; \partial^{2} \mathrm{R} / \partial \pi \partial \mathrm{C}_{\mathrm{T}}=\left(-\alpha(1-\alpha)^{2}\left(1 / 2 \mathrm{C}_{\mathrm{T}}^{2}\right)\right) /(\alpha \pi+(1-$ $\left.\alpha)^{2} / 2 \mathrm{C}_{\mathrm{T}}\right)^{2}+\left(1 / 2 \mathrm{C}_{\mathrm{T}}-1 / 2 \mathrm{C}_{\mathrm{A}}\right)\left(\left(\alpha(1-\alpha)^{4}\left(1 / 2 \mathrm{C}_{\mathrm{T}}^{2}\right)\right) /\left(\alpha \pi+(1-\alpha)^{2} / 2 \mathrm{C}_{\mathrm{T}}\right)^{3}\right)$
} 
Prediction 2a: The tendency of an acquirer to target well-performing firms decreases when the IP of the target country is strengthened.

Prediction 2b: The tendency of an acquirer to target well-performing firms increases when the IP of the acquirer country is strengthened.

In sum, when the acquirer country has stronger IP than the target country, firms with more profitable investment opportunities are more attractive to the acquirer. When the gap in IP becomes greater, the disagreement on the value of control rights increases, increasing the tendency to select well-performing firms.

These predictions also apply to the block share acquisitions, which do not involve complete transfers of control rights. A block share acquisition by a foreign acquirer from a strong-IP country can also increase the costs of diversion for the remaining incumbent controlling shareholders because of additional monitoring from their foreign block shareholders. As a result, such loss of private benefits of control for the incumbent management will also be priced as control premiums.

\section{INVESTOR PROTECTION AND TARGET SELECTION}

In this section, I test Prediction 1 by examining how the strength of investor protection (IP) of target countries affects cross-border target selection by acquiring firms from strong-IP countries.

\section{III.A. EMPIRICAL METHODOLOGY}

I estimate a Probit model to examine how the likelihood of being a target of an acquirer from a strong-IP country is related to firm performance. The dependent variable is a binary choice variable Target $_{i j t}$, equal to one if firm $i$ receives a bid from an acquiring firm in industry $j$ in a strong-IP country $N$ in year $t$, and zero otherwise,

$$
\begin{aligned}
\text { Target }_{i j N t} & =1, \text { if Target }^{*}{ }_{i j N t}>0 \\
& =0, \text { Otherwise }
\end{aligned}
$$

Target ${ }^{*}{ }_{i j N t}$ is a continuous latent variable determined by the following specification: 


$$
\text { Target }_{i j N t}^{*}=\alpha_{j}+\alpha_{t}+\alpha_{N}+\text { OPerform }_{i, t-1}+\lambda Z_{i j N, t-1}+e_{i j N t}
$$

where Perform $_{i, t-1}$ is a measure of firm performance, $\alpha_{j}, \alpha_{t}$, and $\alpha_{N}$ represent industry, year, and target country fixed effects, $Z_{i j N, t-1}$ is a vector of control variables, and $e_{i j N t}$ is the error term. Industries are defined as the first two-digit SIC codes. Industry, year, and country fixed effects are used to control for industry characteristics and related regulations, time trends, and other country factors (e.g., macro economic conditions, business culture, and regulations ${ }^{12}$ ) that may affect both firm performance and target selections. The model is estimated with robust standard errors.

To test Prediction 1, I separate countries into strong-IP and weak-IP target countries and consider acquirers only from strong-IP countries. Thus, $\theta$ is expected to be positive, when targets are located in weak-IP countries. ${ }^{13}$

\section{III.B. DATA}

The full sample covers firms located in 40 countries. These 40 countries are separated into two groups, strong-IP and weak-IP countries based on the strength in their IP. The measure of the strength of IP incorporates both de jure and de facto aspects of regulations. It is a weighted average of the normalized Anti-self-dealing index and Lawand-Order index with 0.2 and 0.8 weights. ${ }^{14}$ Anti-self-dealing index in Djankov et al. (2008) measures de jure minority shareholder protection against controlling shareholders' actions that may hurt shareholder value. This index is country-specific and time invariant.

\footnotetext{
${ }^{12}$ These country-level regulations could be restructuring related regulations or merger-related anti-trust laws. $\mathrm{Lu}$ (2007) demonstrates that regulations making restructuring costly reduce the probability of takeovers of underperforming firms. Kim and Singal (1993) demonstrate that market power is an important motivation of acquisitions. Weaker anti-trust regulations may make it easier to acquire large and well-performing firms. ${ }^{13} \mathrm{An}$ alternative way to test the prediction is employing an interaction of firm performance and the variable indicating the strength of IP of each country with the full sample. I do not employ this method, because it implicitly assumes that the impact of all control variables on the likelihood of being an acquisition target is identical. In fact, the results estimated with the separated samples reveal that some of the control variables have very diverse impacts on the likelihood of being a target under different legal environments.

${ }^{14}$ An alternative de-jure measure is Anti-director index, which was compiled by Laporta et. al (1998) and was subsequently revised by Djankov et al. (2008) in response to the criticism by Pagano and Volpin (2005). I use Anti-self dealing index as the de jure measure and the Law-and-Order index as the de facto measure. How to weight these two measures to construct a measure of IP requires a subjective judgment. A simple approach would be to give an equal weight to each. However, the equal weight approach would rank countries such as China and Thailand ahead of France in terms of IP strength. Although France has Civil law origination, such low relative ranking for France seems unreasonable. Thus, I experiment with different combinations of weights to come up with a reasonable ranking of countries in IP. I choose to give $20-80$ percent weights to the Anti-self-dealing and Law-and-Order indices, at which point Italy is the only G-7 country that ranks as a weak-IP country.
} 
The Law-and-Order index provided by International Country Risk Guide (ICR) measures the effectiveness of the enforcement of formal rules. This index is updated monthly. Yearly averages are used to construct the IP index. Strong-IP and weak-IP countries are separated by the median value of the index. Strong-IP countries include Australia, Austria, Belgium, Canada, Denmark, Finland, France, Germany, Hong Kong, Ireland, Israel, Japan, Netherlands, New Zealand, Norway, Singapore, Sweden, Switzerland, and United Kingdom. Weak-IP countries include Argentina, Brazil, Chile, China, Czech Republic, Greece, India, Indonesia, Italy, Malaysia, Mexico, Peru, Philippines, Poland, Russia, South Africa, South Korea, Spain, Taiwan, Thailand, and Turkey. ${ }^{15}$ Target firms are from all 40 countries, 19 strong-IP and 21 weak-IP countries. To estimate equation (8) and (9), the sample is constructed in the following ways. First, I identify acquisitions using the following criteria.

1. Transactions are cross-border acquisitions and acquirers and targets are located in different countries. Acquirers are from the above 19 strong-IP countries and the U.S. ${ }^{16}$ To remove noise arising from "round-tripping capital," firms' nationalities are defined by the nationalities of their ultimate parents. ${ }^{17}$

2. Acquisitions are announced between January 1, 1993 and December 31, 2006. WorldScope provides data on non-target firms for only from 1992 to $2005{ }^{18}$ Additionally, many emerging economies opened up domestic stock markets to foreign investors in the late 1980s (see Bekaert and Harvey, 2000; Henry, 2000; Kim and Singal, 2000). ${ }^{19}$ Thus, cross-border acquisitions in emerging markets are very few before the early 1990s.

\footnotetext{
${ }^{15}$ The median value of the IP index occurs at Italy and Thailand. Both countries are treated as weak-IP countries, yielding 21 weak-IP countries.

${ }^{16}$ The sample of potential target firms does not include any U.S. firms, because the sample will be dominated by U.S. firms if they are included.

17،"Round-tripping capital" means that capital is originally from a country (usually a developing country), and then routes to another place before re-entering the original country as FDI inflows. In some developing countries (e.g., China), round-tripping capital is a popular phenomenon. For example, Prasad and Wei (2005) estimate that round-tripping capital represents as much as one-third of Chinese FDI. Round-tripping capital often is associated with tax evasion (Fisman and Wei, 2004).

${ }^{18}$ The sample period is one year before the period of the acquisition sample, because the information of target firms is taken in one year before acquisition announcements.

${ }^{19}$ For example, in the early 1990s, Latin American countries began actively seeking foreign investments in their newly privatized industries. In a number of East Asian countries, however, prohibitions on foreign investors gaining a controlling share of local firms continued until the mid-1990s.
} 
3. Both acquirer and target are publicly listed. Thus, by definition, no target firms are owned $100 \%$ by any shareholder, making control premiums relevant to determining acquisition prices.

4. An acquirer does not own any shares of the target before the acquisition. This eliminates pre-existing foreign investor influence on target firm governance.

5. Following Dyck and Zingales (2004), acquisitions involve at least 10\% of target share transfers. This is also consistent with the Bureau of Economic Analysis definition of FDI as a 10\% acquisition of foreign firms' outstanding shares. These screens yield a sample of acquisitions of which the mean and median percentage shares acquired are $72.4 \%$ and $90.73 \%$, respectively.

Because the object is to study target selection, not transaction outcome, I do not distinguish whether acquisitions are successful or unsuccessful. Nor do I distinguish whether acquisitions are friendly or hostile. ${ }^{20}$

WorldScope provides panel data of listed firms located in more than 80 countries and covers both target and non-target firms. SDC Thompson's International M\&A database covers information on M\&As taken place in more than 200 countries. I manually merge data from WorldScope with SDC. The procedures are as follows:

1. Firms covered by WorldScope receiving bids from acquirers from strong-IP countries in a given year are manually identified with information from SDC.

2. Target and non-target firms are matched by country, year, and industry. ${ }^{21}$ For any non-target firm, there must be at least one matched target firm in the same country, year, and industry in the sample.

3. Firm-year observations of target firms following a successful acquisition are excluded from the sample.

These three steps yield a large cross-country, firm-level panel dataset including both target- and non-target firms. The full sample covers 9,580 firm-year observations in

\footnotetext{
${ }^{20}$ Schwert (2000) finds that economic differences between friendly and hostile takeovers are indistinguishable. Under a strong view of managerial entrenchment, managers may wish to avoid any type of changes in control, including those appearing "friendly" in the press.

${ }^{21}$ Industries are defined as the first two-digit SIC codes.
} 
40 countries during the period 1992 to $2005^{22}$. The target sample includes 707 firm-year observations and accounts for $7.38 \%$ of the full sample; the non-target sample includes 8,873 firm-year observations, accounting for the rest of the full sample.

Panel A of Table I shows the country distribution of target and non-target firms. The number of observations varies across countries, partly due to differences in the coverage by SDC and WorldScope. Industrialized countries generally have more observations than do emerging economies. The pair-wise correlation in the number of observations between the target and non-target sample of each country (i.e. Columns (3) and (5)) is 0.95 and significant at the $1 \%$ level, implying that the target and non-target samples are evenly distributed across countries. Panel B of Table I reports the sample distribution for acquirer countries, strong-IP target countries and weak-IP target countries.

\section{III.C. VARIABLES}

\section{III.C.1. FIRM PERFORMANCE VARIABLE}

The primary measure of firm performance is the growth rate of sales to total asset ratio SALES/TA_Gr. This measure is less affected by accounting rules and earnings management than other accounting based performance measures. In addition, Durnev and Kim (2005) show that sales growth rate is positively related to the quality of firm-level corporate governance. I use the growth rate, instead of sales level for two reasons. The first is to eliminate the impact of data coverage bias. Worldscope covers more firms in industrialized countries than in emerging markets. Thus, its coverage of industrialized countries is broader, making the size and performance of firms more diverse, whereas its coverage of emerging markets is narrower. The covered firms tend to be bigger in size or perform better. This bias at the level of performance may be mitigated when performance is measured by the growth rate. The second is that Liu (2008), with data on U.S. acquisitions, shows that changes in performance, rather than performance levels are related to the likelihood of being targeted. To reduce the impact of outliers, SALES/TA_Gr is winsorized at the 1 and 99 percentile.

\footnotetext{
${ }^{22}$ All acquisitions are announced during 1993 to 2006. The sample used to estimate target selection includes both target and non-target firms and covers the period from 1992 to 2005 which is one year lag of the acquisition announcement period.
} 


\section{III.C.2. CONTROL VARIABLES}

Firm-level control variables include firm size (Firm Size), market-to-book ratio $(M B)$, leverage (Leverage), and liquidity (Liquidity), which Palepu (1986) documents are predictors of acquisition targets). Firm Size is $\log$ of the book value of total assets. $M B$ is the ratio of the market value of common equity to the book value of equity. Leverage is the total debt (Long term + Short term debt) divided by the book value of total assets. Liquidity is the ratio of current assets to current liabilities. Firms with negative $M B$ s and Leverage greater than one are dropped from the sample.

Financial crises may affect acquisitions. Aguiar and Gopinath (2005) find financial crises often change M\&A patterns. ${ }^{23}$ To control for the impact of financial crisis on foreign acquisition decisions, an indicator, Crisis 1 , is included in the regressions. It is equal to one if a firm-year observation has any of the following country-year combinations: Thailand, 1997-99; South Korea, 1997-99; Indonesia, 1997-99; Argentina, 2001-02; Brazil, 1998-99; Mexico, 1994-95; Turkey, 1994, and 2000-01; Russia, 1998.

I control for two additional country-level variables that may be related to foreign acquisition decisions. The first is macroeconomic condition, measured as GDP per Capita (GDPPA). Firms in low-income countries may be more capital constrained, making it easier for foreign firms to acquire them. GDPPA is denominated in 2000 U.S. dollars, taken from the World Development Indicators (WDI) for all countries except Taiwan; for Taiwan, it is taken from Global Insights.

The second is country openness, measured as FDI net inflows as percent of GDP (Inward FDI/GDP). It is easier for foreign firms to acquire firms in a country more open to FDI. The openness may induce more competition among acquirers, which increases takeover premiums for local firms (Bradley, Desai, and Kim, 1988). Inward FDI/GDP is an annual country level variable, taken from the WDI for all countries except Taiwan; for Taiwan, it is taken from Global Insights. Summary statistics of all firm-level variables for the full-, target-, and non-target samples are presented in Panel A, B, and C of Table II, respectively.

\footnotetext{
${ }^{23}$ Aguiar and Gopinath (2005) find that the nature of M\&As during a crisis contradicts productivity-based explanations of acquisitions. They also find that the number of foreign M\&As in East Asia increased by 88\% between 1996 and 1998.
} 


\section{III.D.RESULTS}

Table III reports the regression estimates of the Probit analysis of acquisition target selection. All regressions include industry-, year- and target country fixed effects and are estimated with robust standard errors. The regression coefficients are reported in Columns (1) and (3) and the marginal effects of independent variables are reported in Columns (2) and (4). Columns (1) and (2) present the results of target selection by acquirers from strong-IP countries in weak-IP countries. The coefficient of SALES/TA_Gr is positive and significant. It suggests that when SALES/TA_Gr doubles, the likelihood of receiving an acquisition bid from acquirers from strong-IP countries increases by $2.8 \%$ at the mean level. Columns (3) and (4) present the results of target selection by acquirers from strong-IP countries in strong-IP countries. The coefficient of SALES/TA_Gr is insignificant. Thus, acquirers from strong-IP countries appear targeting well-performing firms in weak-IP countries; however, there is no such cherry picking tendency when bidding for firms located in strong-IP countries.

The coefficients on $M B$, one of the firm-level control variables, also exhibit a similar but stronger pattern. Firms with higher $M B$ are more likely to become acquisition targets only in weak-IP countries. Since $M B$ measures investors' expectation of firms' future performance, the $M B$ results also imply that acquirers from strong-IP countries target well-performing firms in weak-IP countries but not in strong-IP countries. In sum, the regression estimates suggest that target selection decisions of acquirers from strongIP countries depend on the strength of host countries' IP. In weak-IP countries, they cherry pick well-performing firms, but reveal no such preferences in strong-IP countries.

\section{CORPORATE GOVERNANCE REFORMS AND TARGET SELECTIONS}

In this section, I test the other prediction of the model concerning the effect of changes in IP on target selection. Specifically, I analyze how acquirers from strong-IP countries change their target selection decisions in response to the CGRs undertaken in the target countries and to the CGRs undertaken in their own countries. To this end, I first

identify a series of influential CGRs. To the extent that CGRs enhance IP, the gap in IP between the acquirer and target countries will be narrowed by CGRs undertaken by target countries and enlarged by CGRs undertaken by acquirer countries. Since CGRs are 
undertaken by different countries at different points in time, the staggered passages of CGRs allow estimation of their impacts on target selections with a difference-indifference approach.

\section{IV.A. CORPORATE GOVERNANCE REFORMS}

\section{IV.A.1. BACKGROUND}

CGRs are defined as deliberate interventions in a country's corporate governance traditions by the state, the local security and exchange commission, or local stock exchanges. Usually, CGRs are undertaken in the forms of publishing a set of codified corporate governance norms or the amendments of countries' corporate law or security law pertaining to such issues as the role and composition of the board of directors; the installment of board subcommittees (e.g., audit, compensation, and nomination committees); the appointment and rules of operation applying to external auditors; the distribution of rights and powers over professional managers, shareholders, and other stakeholders; the role of media in information dispersion; and the protection of whistle blowers (Aguilera and Cuervo-Cazurra, 2004). Typical examples of CGRs around the world include the Clause 49 (India, in 1999), the Corporate Law Economic Reform Program (CLERP 9) (Australia, in 2004), and Sarbanes-Oxley Act of 2002 (the U.S., 2002).

Recent worldwide CGRs are activated by three major motivations, which are indistinguishable in many countries. The first motivation is international pressure for domestic institutional evolution. For example, some CGRs are performed by the governments to build up local companies' competitiveness in global markets. In addition, the OECD issued its corporate governance principles in 1999 and 2004. ${ }^{24}$ These principles have produced pressures to the policymakers, regulators, and market participants of member countries to improve their corporate governance. The impact of these principles is not restricted to OECD countries. Recently, they have been used extensively by the World Bank as a framework for policy dialogue to promote regional

\footnotetext{
${ }^{24}$ OECD corporate governance principles $(1999,2004)$ is one of the most important and influential standards of corporate governance worldwide. There are six broad principles: ensuring the basis for an effective corporate governance framework; the rights of shareholders and key ownership functions; the equitable treatment of shareholders; the role of stakeholders in corporate governance; disclosure and transparency; the responsibilities of the board.
} 
CGRs and for roundtable discussions in non-OECD countries. The participation of most non-OECD countries confirms the adaptability of the OECD principles as a reference in varying legal, economic, and cultural contexts. ${ }^{25}$

The second motivation for reform is financial crises. Weak corporate governance is generally considered an important contributor to the Asian 1997 financial crisis (e.g., Johnson et al., 2000). CGRs are an important component of the post-crisis restructuring process for crisis affected countries. For example, the Korean government responded to its 1997 financial crisis by amending the Commercial Code and the Securities Exchange Act to change the country's corporate governance tradition. The reform efforts have had noticeable impacts on accountability, transparency, and governance structure (Kim and Kim, 2008).

The third motivation is big corporate scandals. Sarbanes-Oxley Act of 2002 (SOX) is a typical scandal motivated CGR. It aims to strengthen corporate governance of U.S. listed firms. It has 11 sections, which can be grouped under three headings: board-related changes; changes in disclosure and accounting rules; audit-related changes. Additionally, the U.S. business scandals and SOX have had a broad influence on corporate governance systems around the world. For example, in response to the collapse of Enron and WorldCom, the UK introduced the new Combined Code on Corporate Governance. The Code was issued in July, 2003 by the Financial Reporting Council, and was put into effect on November 1, 2003. The issuance of this Code is viewed as the most important recent development of corporate governance in the UK. (Global Corporate Governance Guide 2004; Hodge, 2007). Furthermore, many countries had their own share of corporate scandals (e.g., Lernout \& Hauspie in Belgium; Yin Guang Xia in China; Vivendi in France; Leo Kirch in Germany; Parmalat in Italy), which served warning to the local governments to improve their corporate governance systems. Appendix 2

\footnotetext{
${ }^{25}$ The roundtable dialogues have resulted in some common corporate governance issues across participating developing countries: strengthening effective legal enforcement; protecting shareholders with particular focus on minority owners; dealing with conflicts of interest; strengthening company oversight by boards. Additionally, in response to the OECD principles, various regional organizations around the world have devised their own corporate governance principles to enhance corporate governance environments in their regions. Organizations such as the Asia-Pacific Economic Cooperation (APEC), Pacific Economic Cooperation Council (PECC), Asian Development Bank (ADB), Commonwealth Association of Corporate Governance (CACG), European Commission (EC), and the UN Economic Commission for Africa (UNECA) have published their own principles.
} 
contains the details of how international pressures, financial crises, and scandals have stimulated CGRs in the sample countries.

\section{IV.A.2. IDENTIFYING THE CGRS OF SAMPLE COUNTRIES}

To identify CGRs, I collect information by searching websites of European Corporate Governance Institute, Asian Corporate Governance Association, the International Finance Corporation (IFC) at the World Bank, Financial Standards Foundation, and countries' stock exchanges, book chapters, journal articles, and media news through Factiva.

In many countries, improving corporate governance is a gradual process involving multiple regulation regimes. The most effective and influential one of each country is considered the CGR of the country. The identification criteria are as follows:

1. The central intent of a CGR is to improve financial transparency, provide monitoring by independent board members or audit systems, empower shareholders, and establish effective legal systems. The content of a CGR generally focuses on the following four issues: enhancing disclosure requirements; strengthening the mechanisms of internal governance by specific requirements concerning the role and composition of the board of directors; empowering shareholders; and toughening public enforcement.

2. A CGR should apply to most publicly listed firms. ${ }^{26}$ Some CGRs, such as Clause 49 in India, do not apply to very small firms. Clause 49 is still considered the CGR of India, because it has been documented to be the most important regulation regime on corporate governance system in India by many studies (e.g. Clarke, 2007; Black and Khanna, 2007; Dharmapala and Khanna, 2008).

3. A CGR must involve legal rules or comply-or-explain regulations rather than purely voluntary recommendations. $^{27}$

\footnotetext{
${ }^{26}$ Some regulations apply only to a subgroup of firms instead of all publicly listed firms in the country. For example, in Finland, Handling of Corporate Governance Issues (2000) only applies to State-Owned companies and their associated companies. These regulation regimes are not considered the CGRs.

${ }^{27}$ In practice, there are three types of regulations: legal based rules, comply-or-explain regulations, and voluntary compliance recommendations. Since voluntary regulations (e.g., Danish Shareholders' Association Guidelines of 2000 and Berlin Institutive Code of 2000) do not have precise enforcement date and criteria, they are not considered CGRs.
} 
4. A CGR has generally positive comments on the effectiveness. ${ }^{28}$ When phrases, such as "milestone" or "the most important development", are used to describe the outcome of the new rules, I infer that the rules are effective.

Although the regulations contained by these CGRs are not identical, thesescreening criteria generate strong commonalities in the applicable firms targeted, central intents, contents, and their effectiveness. Although they may not be directly comparable across countries, these CGRs help identify the years in which a significant improvement in investor protection took place in the sample countries.

When a country has multiple regulatory regime changes that are more or less equivalent, the earliest one is considered the CGR of the country. In as much as each regime change is part of a broader set of legal reforms geared toward enhanced corporate governance system, the earlier one contains implicit information about the future schedule of corporate governance improvement. Appendix 2 describes each CGR and how the CGR year of each country is defined.

\section{IV.B. EMPIRICAL METHODOLOGY}

In this section, I examine when strong-IP countries' firms select targets in weakIP countries, how the type of firms being targeted is affected by CGRs performed by target countries and their home countries. Since CGRs are undertaken by different countries at different points in time, the staggered passages of CGRs allow estimation of CGRs' impact on target selections with a difference-in-difference approach. A similar approach has been used in Branstetter, Fisman, and Foley (2006).

The gap in IP between acquirer and target countries can be changed by either a change in IP of the target country or that of the acquirer country. I firstly start with the impact of a CGR in the target country. To illustrate this approach, consider a CGR in Korea in 1999. To estimate the effect of the CGR in Korea, I compare the type of Korean firms being targeted of acquisitions between pre- and post-1999. However, other events in 1999 may also have an impact on the type of firms being targeted in Korea. Using the acquisitions taken place in a country not undertaking a CGR in 1999 (e.g., China, which

\footnotetext{
${ }^{28}$ Some regulation regimes may not significantly affect country's corporate governance system. For example, Japan enacted some new regulations in 2002 to introduce more "U.S.-style" governance practices. However, the outcome was not encouraging. So, this legislative activity in Japan is not considered a CGR.
} 
experienced a CGR in 2002) would help control for other changes in the type of firms being targeted in 1999. The difference of those two differences, $\delta$ serves to identify the impact of the CGR undertaken in Korea on the target selection of Korean firms by acquirers from strong-IP countries. The type of firms being targeted is defined as preacquisition performance of target firms. I expect $\delta$ to be negative; namely, the tendency of acquirers from strong-IP countries to select well-performing firms reduces after the target country undertakes a CGR. One important distinction between this example and the regression framework is that the regression accounts for many CGRs staggered over time. These staggered passages of CGRs implicitly treat all acquisitions taken place in countries not enacting CGRs at time $t$ to be the control group of the acquisitions taken place in countries which undertake CGRs at time $t$.

The impact of CGRs undertaken by acquirer countries on the type of firms being targeted can be identified by the same approach. The staggered passages of CGRs of acquirer countries implicitly treat all acquisitions by acquiring firms in countries not enacting CGRs at time $t$ to be the control group of the acquisitions by the acquiring firms located in countries which undertake CGRs at time $t$. CGRs undertaken by acquirer countries have an opposite effect on the type of firms being targeted; namely, the tendency of a foreign acquirer from a strong-IP country to select well-performing firms increases after the acquirer country undertakes a CGR, which potentially enlarges the IP gap with the target country, if the target country does not undertake a CGR in the same year.

The sample is constructed at the deal level. Since there are no multiple acquisitions of one target firm in the sample, each deal is associated with one unique target firm. The specification is:

$$
\begin{aligned}
& \text { Perform }_{\text {ijmnkt }}=\alpha+\gamma X_{i j m n k t}+\delta T C G R_{n t}+\lambda A C G R_{m t}+\sum_{j=1}^{J-1} d_{j}+\sum_{t=1}^{T-1} d_{t}+\sum_{m=1}^{M-1} d_{m}+ \\
& \sum_{n=1}^{N-1} d_{n}+e_{i j m n k t},
\end{aligned}
$$

where $i$ indexes deals (target firms); $j$ indexes industries of target firms; $k$ indexes acquirers; $m$ indexes acquirer countries; $n$ indexes target countries; $t$ indexes time; The dependent variable is Perform ${ }_{i j m n}$, measured as SALES/TA_Gr in the year prior to the announcement of the acquisition bid; $d_{j}$ is target industry dummy; $d_{t}$ is year dummy; $d_{m}$ 
$\left(d_{n}\right)$ is acquirer (target) country dummy; $X_{i j m n t}$ is a vector of control variables; $A C G R_{m t}$ $\left(T C G R_{n t}\right)$ is an indicator that equals one if the CGR has been undertaken by year $t$ in the acquirer (target) country $m(n)^{29} ; e_{i j m n k t}$ is error terms. Regressions are estimated with robust standard errors.

IV.C. DATA

To estimate Regression (10), the sample is constructed at the deal level. The full sample includes 273 cross-border acquisitions, which are announced from January 1, 1991 to December 31, 2007. These acquisitions are taken place in 21 weak-IP target countries associated with acquirers from 17 strong-IP countries. ${ }^{30}$ The acquisition screening criteria are the same as before, but the number of target firms is greater, because this approach allows the inclusion of targets that do not have matched non-target firms in WorldScope. The sample includes 205 and 68 acquisitions before and after CGRs of the target countries, respectively. It includes 215 and 58 acquisitions taken place before and after the passage of CGRs of the acquirer countries. Panel A (Panel B) of Table IV presents the sample distribution by target (acquirer) countries.

\section{IV.D. IMPACT OF CGRS ON THE TYPES OF FIRMS BEING TARGETED}

Table V presents the regression estimates of the impact of CGRs undertaken in either target or acquirer countries on the type of firms being targeted by acquirers from strong-IP countries. The estimated coefficients of main interest are $\delta$ on TCGR and $\lambda$ on ACGR.

Column (1) provides the baseline estimates. The results are consistent with the predictions. The coefficient of TCGR is negative and statistically significant at the 5\% level, indicating that acquirers from strong-IP countries are more willing to target underperforming firms after a target country enacts a major CGR. The coefficient of $A C G R$ is positive and statistically significant at the $10 \%$ level, suggesting that the cherry picking tendency increases after the acquirer country undertakes a CGR, enlarging the IP gap.

\footnotetext{
${ }^{29}$ The CGR year of each country can be found in Appendix 2.

${ }^{30} \mathrm{We}$ lost some acquirer countries (i.e. Ireland, Israel, and New Zealand), because this analysis focuses only on strong-IP countries' cross-border acquisitions in weak-IP countries and no acquisitions associated with acquirers from these three countries.
} 
In the baseline regression, I control for deal-, target firm-, and target countryspecific variables. Cross List is an indicator for cross-listing of the target shares in a foreign stock exchange at the time of an acquisition announcement. Cross-listed firms are affected by corporate governance regulations of both countries and, hence, may practice higher quality governance. ${ }^{31} \mathrm{Num}$ of Deals is the number of cross-border acquisitions undertaken in each target country during each year. It is used to control for the impact of merger waves in a particular country during a particular year. CGRs may increase the number of foreign acquisitions by improving domestic legal environment, which in turn may generate greater variation in the types of firms being targeted. Horizontal is an indicator variable equal to one, if the acquirer and target are sharing the same first two-digit SIC codes. Horizontal and vertical acquisitions are motivated by different corporate strategic motivations and, thus, may lead to different target selection decisions. GDPPA Ratiois the ratio of GDP per capita of the target country to that of the acquirer country one year prior to the acquisition announcement. When the target country's relative economic development is closer to the acquirer's country, the acquirer may be more willing to pursue poorly performing firms to enter a market with greater purchasing power. Or the relative income ratio may pick up the gap in investor protection my measure of IP does not capture. Finally, Crisis 2 is an indicator, equal to one if the observation is in the following country-year combinations: Thailand, 1997-99; South Korea, 1997-99; Indonesia, 1997-99; Argentina, 2001-02; Brazil, 1998-99; Mexico, 1994-95; Turkey, 1994, and 2000-01; Russia, 1998. Acquirers may alter their acquisition strategies in response to a financial crisis in the host country.

Of these control variables, only GDPPA Ratio is significant. The negative sign suggests that acquirers' cherry picking tendency is less pronounced when they enter a market with greater purchasing power.

The occurrence of CGRs may not be exogenous, at least with respect to the acquisition decisions. Omitting factors affecting the occurrence of CGRs may bias the results. The earlier discussion on CGR offers two identifiable factors affecting the occurrence of CGRs: financial crisis and business scandals. The baseline model

\footnotetext{
${ }^{31}$ For a robustness check, I control for an ADR dummy, instead of this Cross List dummy, and the results are unchanged.
} 
specification accounts for financial crisis. In Column (2) I account for business scandals in target or acquirer countries. ${ }^{32}$ The existence of business scandals may reflect the general quality of pre-CGR corporate governance of the country, which could be associated with their cross-border acquisition activities. I follow Duflo (2001) and include two variables. THaveScandal is an indicator, equal to one if the target country has undertaken the CGR when the acquisition is announced and some big business scandals took place in or before the CGR year in this target country. AHaveScandal is an indicator equal to one if the acquirer country has undertaken the CGR when the acquisition is announced and some big business scandals took place in or before the CGR announcement year in the acquirer country. The estimated coefficients on both TCGR and $A C G R$ are largely unaffected by the inclusion of these two indicator variables in terms of both magnitude and the level of significance. If there are any, both magnitude and significance increase with these control variables. In addition, the positive coefficient of THaveScandal indicates that CGRs initiated by business scandals in weak-IP target countries is less effective in reducing the cherry picking tendency by foreign acquireres. Perhaps the scandals have a lingering effect, partially offsetting the investor confidence enhancing effect of CGRs.

Other potentially important omitted variables in the regression are firm characteristics, when legal environments change, the changes may also affect the types of firms being targeted by affecting acquirers' operating strategies. To address this concern, Column (3) conducts a robustness check by controlling for Acquirer Size and Acquirer Tobin's $Q$. Acquirer Size is measured as the logged value of total assets of the acquirer one year before the announcement of the acquisitions. Acquirer Tobin's $Q$ is measured as a ratio. The numerator is the book value of total assets plus the market value of equity and minus the book value of equity. Due to the data availability of Acquirer Size and Acquirer Tobin's $Q$, the sample size is reduced to 160. The results on TCGR and ACGR are robust.

\footnotetext{
${ }^{32}$ The earlier discussion also points out international pressures for institutional reforms as another motivating factor for CGRs. This international pressure is best captured in the issuance of OECD Corporate Governance Principles in 1999 and 2004. Most acquirers in the sample are from OECD countries and most target firms are located in non-OECD countries. Thus, this motivating factor for CGRs is likely to be captured in the grouping of countries into acquirer and target countries.
} 
An important concern with these OLS results is that the changes in targets' preacquisition performance may simply reflect the changes in the performance of all firms in the same country, industry, and year, either coinciding or triggered by the country's CGR. To address this concern, Columns (4) and (5) conduct a robustness check by accounting for the change in the location of the target firm in the distribution of all firms' performance in the same country, year, and industry. The dependent variable now is the numerical cumulative density functions (CDFs) of a target firm's SALES/TA_Gr based on all available observations with the same country, year, and industry (defined as the firsttwo digit SIC codes) in WorldScope. CDF represents the relative performance position of a firm in its country-year-industry matched sample. It also reduces the importance of outliers by normalizing the variable into a unit interval. The result reported in Column (4) is estimated with the OLS. However, the value of the CDFs is truncated by zero and one; thus, Column (5) estimates the relation with a standard censored Tobit model (i.e. type I Tobit model). Both estimation methods yield similar results. One weakness of the CDF approach is that it is based on the number of observations in each country-year-industry specific sample. When the number of observations is small, which typically is the case in emerging market countries, $\mathrm{CDF}$ is a noisy measure of relative performance. With this built-in bias, the results are still robust. The coefficient of TCGR implies that after a target country undertakes a CGR, the pre-acquisition performance of target firms is about 28.8 percentile lower within the country-year-industry matched sample. Conversely, after an acquirer country undertakes a CGR, acquirers domiciled in that country tend to pursue firms with pre-acquisition performance 23.2 percentile higher within the country-yearindustry matched sample. ${ }^{33}$

In sum, the tendency to select well-performing firm decreases, when the distance in IP is narrowed by the CGR undertaken by a target country. Conversely, this tendency increases, when the IP cap is enlarged by strengthening IP regulations in the acquirer country. All the findings indicate that whether the IP gap is measured by the difference in the level between countries or by changes within a country, the cherry picking tendency

\footnotetext{
${ }^{33}$ These CDF regressions also show that coefficient of Acquirer Size is positive and significant at $10 \%$ level, raising the possibility that bigger acquirers are more inclined to do cherry picking.
} 
by foreign acquirers is largely explained by the IP gap between the acquirer and target countries.

\section{IV.E. TIMING OF REFORMS AND CONFOUNDING EFFECTS}

Although non-random occurrence of CGRs caused by business scandals has been accounted for in Table V, there may be other changes coincident with CGRs that drive both the changes in the legal IP environment and the measured changes in the target selection behavior. For example, once a country reaches a certain threshold level of development, internal and external pressure may build for stronger corporate governance system. Alternatively, pressure by foreign investors may cause countries to adopt reforms when companies have a need to increase foreign capital, such as Clause 49 in India.

These alternative explanations can not be completely ruled out. To examine their plausibility, I borrow a method from Branstetter, Fisman, and Foley (2006). The explanations based on coincident changes in economic and business conditions and the reverse causation may predict that the type of firms being targeted begins to change in the years prior to the CGR year. Thus, the specifications displayed in Table VI provide more detailed estimates of the timing of changes in the type of firms being targeted. The specification is similar to those in Table $\mathrm{V}$ and they yield coefficient estimates for a set of dummy variables that correspond to periods before and after a CGR. The TCGR_t-3 dummy is equal to one for all years that predate the CGR undertaken by the target country by three or more years and is equal to zero in all other years, and the TCGR_t+l dummy is equal to one for all years at least one years after the CGR undertaken by the target country and zero during other years. ${ }^{34}$ The other reform dummies are equal to one in specific year relative to the CGR and zero during other years. It is not possible to have a dummy for the year immediately preceding reform (i.e. year t-1), because thecoefficients on the reform dummies provide estimates relative to that year. A set of dummies of $A C G R$ is constructed based on a similar approach.

The results presented in Table VI suggest that the coefficients on the dummies foryears prior to TCGR are insignificant and fail to show any evidence of a clear trend in

\footnotetext{
${ }^{34}$ Although Branstetter, Fisman, and Foley (2006) employ a window of fixed 3-year before and after the reform, I do not include $t+2$ and $t+3$ ted, because most CGRs are enacted in the 2000s, providing insufficient observations for those years.
} 
the changes in the type of firms being targeted prior to the reform. The coefficients on the dummies for the year of reform and post-TCGR years are negative and significant at $1 \%$ level. Thus, the estimated timing of changes is consistent with a shift in activities that follows soon after the enactment of the CGRs undertaken by target countries. A similar but weaker pattern is found for the dummies of $A C G R$. This suggests that CGRs undertaken by target countries may lead to a fairly rapid reaction for cross-border investment activities. But the CGRs enacted by acquirers' home countries seem to require longer time to have an influence on their foreign acquisition decisions.

Another possible concern is that during year $t$, non-CGR countries may also have some legislative events, which are not considered CGRs but may also have an influence on legal environments; thus, the acquisitions in countries not enacting CGRs in year $t$ may not be good control group for the acquisition targets or acquirers in countries enacting the CGRs in year $t$. Since these legislative events are more likely to strengthen than weaken IP, their presence in non-CGR countries will weaken the power of the test

Finally, one may also argue that if foreign firms always favor well-performing firms in weak-IP countries, the number of the available well-performing target firms could be reduced over time. Thus, the negative effect of $T C G R$ could be due to time trend effects. This may not be a concern in the paper, because $A C G R$ is found to have a positive effect on the tendency to cherry pick, indicating that there are enough wellperforming firms to select as takeover targets.

\section{IV.F. ADDITIONAL ROBUSTNESS TESTS}

This section contains the brief description of results obtained in additional robustness checks. First, I estimate specifications with additional control variables. Foreign acquisitions of state owned enterprises (SOEs) could be a part of privatization of the country, which sometimes coincides with other regulatory regimes such as a CGR. For example, a large scale of privatization activates the CGR in Brazil. SOEs may have some uniqueness with respect to firm performance and governance. When controlling for an indicator of SOE target firms, the results do not change and the coefficient of SOE is insignificant. Legal environments may also have an influence on the attributes of acquisitions. For example, Faccio and Masulis (2005) demonstrate that legal 
environments can affect the choice of payment in M\&As. Acquisitions with various attributes could be associated with different types of targets. Thus, rather than CGRs affect target selection, they may affect the type of deals, and hence affect the type of firms being targeted. The results are robust to controlling for the indicators of friendly acquisitions, tender offer, and cash payment, the potential omitted deal characteristics.

Second, to eliminate some data noise, I repeat the above analyses with the following sub-samples. The results are robust after excluding the acquisitions with target firms in financial services and utilities industries and robust with the sample including the acquisitions of at least $20 \%$ of the outstanding target shares. I also restrict the sample to be only successful acquisitions. The results are similar but weaker in significance. This could be due to a bias caused by government interventions in cross-border acquisitions.

\section{V.SUMMARY}

This paper provides an explanation on the well-documented but little understood phenomenon on international capital flows, namely "cherry picking." An acquirer from a strong-IP country values control premiums less than does an incumbent controlling shareholder in a weak-IP country. Such an acquirer will favor well-performing firms, because the controlling shareholders of these firms have the incentive to self-select better governance and require lower control premiums. Although these firms' shares will be valued higher, the lower premiums make them more palatable targets to acquirers who are subject to stronger-IP regulations and can not consume as much private benefits as the average controlling shareholder in a weak-IP country. This cherry picking tendency becomes stronger as the IP gap between the acquirer and target countries becomes bigger.

These predictions are tested with data on 20 strong-IP countries' cross-border acquisitions in 40 countries. The acquirers tend to target well-performing firms only in weak-IP countries, but not in strong-IP countries. When focusing only on strong-IP countries' cross-border acquisitions in weak-IP countries, I find that the acquirers exhibit greater willingness to target underperforming firms after the weak-IP target countries undertake CGRs. CGRs undertaken by the acquirer countries have the opposite effect of increasing the acquirers' tendency to pursue well-performing firms. 
These findings imply that weak IP of host countries impedes local firms most in need of capital and with great room for improvement from gaining access to foreign investors acquirers with managerial and technological know how. More generally, the results in this paper highlight the important role IP plays in guiding international capital flows not only across countries, but also in allocating international capital flow within a country. Finally, recent studies (e.g., Rossi and Volpin, 2004; Bris and Cabolis, 2009) demonstrate that cross-border acquisitions work as an important channel of transferring corporate governance system from better to weak legal protection countries. However, the results of this paper imply that with the disparity in investor protection between countries, the transmission of governance systems through cross-border acquisitions market will occur only for the firms that already have relatively sound governance systems, leaving firms with weak governance untouched. Thus, governance reforms undertaken by developing nations not only directly impact the quality of domestic firms' governance but also provide important indirect impacts by inducing foreign acquirers to reach out to less well-performing firms they have neglected before. 


\section{REFERENCE:}

Aguiar, Mark and Gita, Gopinath, "Fire-sale FDI and liquidity crises," Review of Economics and Statistics, 87 (2005), 439-452.

Aguilera, Ruth V. and Alvaro Cuervo-Cazurra, "Codes of good governance worldwide: What is the trigger?" Organization Studies 25 (2004), 417-446.

Aitken, Brian and Ann E. Harrison, "Do domestic firms benefit from direct foreign investment?" American Economic Review 89 (1999), 605-618.

Alfaro, Laura, Sebnem Kalemli-Ozcan and Vadym Volosovych, "Why doesn't capital flow from rich to poor countries? An empirical investigation," Review of Economics and Statistics 90 (2008), 347-368.

Andrade, Gregor, Mark L. Michell, and Erik Stafford, "New evidence and perspectives on mergers," Journal of Economic Perspectives, 15 (2001), 103-120.

Atanassov, Julian and E. Han Kim, "Labor and corporate governance: International evidence from restructuring decisions," Journal of Finance, 64 (2009), 341-374.

Barclay, Michael and Clifford Holderness, "Private benefits of control of public corporations," Journal of Financial Economics, 25 (1989), 371-395.

Bekaert, Geert, and Campbell R. Harvey, "Foreign speculators and emerging equity markets, Journal of Finance, 55 (2000), 565-613.

Bethel, Jennifer E., Julia P. Liebeskind and Tim Opler, "Block share purchases and corporate performance,” Journal of Finance, 53 (1998), 605-634. 
Bertrand, Marianne and Sendhil Mullainathan, "Enjoying the quiet life? Corporate governance and managerial preferences," Journal of Political Economy 111 (2003), 1043-1075.

Bradley, Michael, Anand Desai, and E. Han Kim, "Synergistic Gains from Corporate Acquisitions and their Division Between the Stockholders of Target and Acquiring Firms," Journal of Financial Economics, 21 (1988), 3-40.

Branstetter, Lee, Fritz Foley, Raymond Fisman, "Do stronger intellectual property rights increase international technology transfer? Empirical evidence from U.S. firm-Level panel data," Quarterly Journal of Economics, 121 (2006), 321-349.

Bris, Arturo and Christos Cabolis, "The Value of Investor Protection: Firm Evidence form Cross-Border Mergers" Review of Financial Studies, forthcoming, 2009.

Chari, Anusha, Paige P. Ouimet, and Linda L. Tesar, "The value of control in emerging markets," Working Paper, 2004, University of Michigan.

Clarke, Thomas, International Corporate Governance: A comparative approach, Routledge, ISBN 041532310x, 9780415323109, 2007.

Djankov, Simeon, Rafael La Porta, Florencio Lopez-de-Silanes, and Andrei Shleifer, The law and economics of self-dealing, Journal of Financial Economics 88 (2008), 430-465.

Doidge, Graig; G. Andrew Karolyi, Rene M. Stulz, Why are Foreign Firms Listed in The U.S. Worth More? Journal of Financial Economics, 71 (2004), 205-238.

Duflo, Esther, "Schooling and labor market consequences of school construction in Indonesia: Evidence from an unusual policy experiment," American Economic Review, 91 (2001), 795-813. 
Durnev, Art and E. Han Kim, "To steal or not to steal: Firm attributes, legal environment, and valuation," Journal of Finance, 60 (2005), 1461-1493.

Dyck, Alexander and Luigi Zingales, "Private benefits of control: An international comparison," Journal of Finance 59 (2004), 537-600.

Faccio, Mara and Ronald W. Masulis, "The Choice of Payment Method in European Mergers and Acquisitions," Journal of Finance, 60(2005), 1345-1388.

Ferreira, Miguel A. and Pedro Matos, "The colors of investors' money: The role of institutional investors around the world," Journal of Financial Economics 88 (2008), 499-533.

Fisman, Raymond and Shang-Jin Wei, "Tax rates and tax evasion: Evidence from "missing imports" in China," Journal of Political Economy 112 (2004), 471-496.

Gelos, R. Gaston and Shang-Jin Wei, "Transparency and international portfolio holdings," Journal of Finance, 60 (2005), 2987-3020.

Haskel, Jonathan E., Sonia C. Pereira, and Matthew J. Slaughter, "Does inward foreign direct investment boost the productivity of domestic firms?" Review of Economics and Statistics 89 (2007), 482-496.

Henry, Peter B., "Stock market liberalization, economic reform, and emerging market equity prices," Journal of Finance 55 (2000), 529-564.

Kim, E. Han, and V. Singal, "Mergers and market power: Evidence form the Airline Industry,” American Economic Review, 83 (1993), 549-569.

Kim, E. Han, and V. Singal, "Stock market openings: Experience of emerging economies," Journal of Business, 73 (2000), 25-66. 
Kim, E. Han, and Woochan Kim, "Changes in Korea corporate governance: A response to crisis," Journal of Applied Corporate Finance 20 (2008), 47-58.

Kim, Woochan, Taeyoon Sung, and Shang-Jin Wei, "Does Corporate Governance Risk at Home Affect Investment Choices Abroad?" SSRN Working Paper, 2008.

Johnson, Simon, Peter Boone, Alasdair Breach, and Eric Friedman, "Corporate governance and the Asian financial crisis," Journal of Financial Economics, 58 (2000), 141-186.

Lang, Larry H.P., Annette Poulsen, and Rene Stulz, "Asset sales, firm performance, and the agency costs of managerial discretion," Journal of Financial Economics, 37 (1995), 3-38.

Lang, Larry H.P., Rene M. Stulz and Ralph A. Walkling, "Managerial performance, Tobin's Q and the gains from successful tender offers," Journal of Financial Economics, 24 (1989), 137-154.

La Porta, Rafeal, Florencio Lopez-de-Silanes, Andrei Shleifer, "Legal determinants of external finance," Journal of Finance, 52 (1997), 1131-1149.

-----“Corporate ownership around the world,” Journal of Finance, 54 (1999), 471-517.

La Porta, Rafeal; Florencio Lopez-De-Silanes, Andrei Shleifer and Robert Vishny, "Law and finance," Journal of Political Economy, 106 (1998), 1113-1155.

----“Investor protection and corporate valuation," Journal of Finance, 57 (2002), 11471170.

Leuz, Christian, Karl V. Lins, and Francis E. Warnock, "Do foreigners invest less in poorly governed firms?" Review of Financial studies, forthcoming. 
Liu, Yang, "The real determinants of assets sales," Journal of Finance, 63 (2008), 22312262.

Lu, Yao, "Is cheaper always more attractive? Target attributes and gains from takeovers in different legal environments," Working Paper, 2007, University of Michigan.

Loughran, Tim and Anand Vijh, "Do long-term shareholders benefit from corporate acquisitions?" Journal of Finance, 52 (1997), 1765-1790.

Maksimovic, Vojislav and Gordon Phillips, "The market for corporate assets: Who engages in mergers and asset sales and are there efficiency gains?" Journal of Finance, 56 (2001), 2019-2065.

Martin, Kenneth J., "The method of payment in corporate acquisitions, investment opportunities, and managerial ownership," Journal of Finance 51 (1996), 1227-1246.

Nenova, Tatiana, "The value of corporate voting rights and control: A cross-country analysis," Journal of Financial Economics, 68 (2003), 325-351.

Norton, Edward C., Hua Wang, and Chunrong Ai, "Computing interaction effects and standard errors in logit and probit models," Stata Journal 4 (2004), 103-116.

Pagano, Marco and Paolo Volpin, "The Political Economy of Corporte Governance, American Economic Review, 95 (2004), 1005-1030.

Palepu, Krishna G., Predicting takeover targets: A methodological and empirical analysis, Journal of Accounting and Economics, 8 (1986), 3-35.

Prasad, Eswar and Shang-Jin Wei, The Chinese approach to capital inflows: Patterns and possible explanations, NBER Working Paper No. 11306, 2005. 
Rau, P. Raghavendra and Theo Vermaelen, "Glamour, value and the post-acquisition performance of acquiring firms," Journal of Financial Economics, 49 (1998), 223-253.

Rossi, Stefano and Paolo F. Volpin, "Cross-country determinants of mergers and acquisitions, Journal of Financial Economics, 74 (2004), 277-304.

Sabirianova, Klara, Jan Svejnar, and Katherine Terrell, "Distance to the efficiency frontier and foreign direct investment spillover," Journal of the European Economic Association Papers and Proceedings, 3 (2005), 576-586.

Schwert, G. William, "Hostility in takeovers: In the eyes of the beholder?" Journal of Finance, 55 (2000), 2599-2640.

Servaes, Henri, “Tobin's Q and the gains from takeovers,” Journal of Finance, 46 (1991), 409-419.

Shleifer, Andrei, and Daniel Wolfenzon, "Investor protection and equity markets," Journal of Financial Economics, 66 (2002), 3-27.

Asian Corporate Governance Association (http://www.acga-asia.org/index.cfm). eSTANDARDSFORUM (http://www.estandardsforum.org).

European Corporate Governance Institute (http://www.ecgi.org/).

Global Corporate Governance Guide 2004

(http://www.globalcorporategovernance.com/).

The World Bank Group, Doing Business (http://www.doingbusiness.org/CustomQuery/). 


\section{Appendix 1: Variable Description}

\begin{tabular}{|l|l|}
\hline Panel A: Legal Variables & (Note: A higher score indicates stronger investor protection) \\
\hline & $\begin{array}{l}\text { Measures the amount of disclosure before and after the transaction has occurred, the need for approval by disinterested shareholders } \\
\text { and litigation governing a specific self-dealing transaction. It is time invariant and at the country level. (Source: Djankov, et al } \\
(2008))\end{array}$ \\
\hline Law-and-Order & $\begin{array}{l}\text { Measures the strength and impartiality of the legal system and of the popular observance of the law. It is annual frequency and at the } \\
\text { country level. (Source: International Country Risk Guide) }\end{array}$ \\
\hline IP & Measured as $(0.2 *$ Anti-self-dealing $+0.8 *$ Law-and-Order). \\
\hline
\end{tabular}

Panel B: Corporate Governance Reform Variables

\begin{tabular}{|c|c|}
\hline TCGR & $\begin{array}{l}\text { An indicator, which is equal to one if an influential CGR (see Appendix 2) has been undertaken in the target country, when the } \\
\text { acquisition bid is announced. }\end{array}$ \\
\hline$A C G R$ & $\begin{array}{l}\text { An indicator, which is equal to one if an influential CGR (see Appendix 2) has been undertaken in the acquirer country, when the } \\
\text { acquisition bid is announced. }\end{array}$ \\
\hline THaveScandal & $\begin{array}{l}\text { An indicator, which equals one if the target country has undertaken the CGR when the acquisition is announced and some big business } \\
\text { scandals took place in or before the CGR announcement year in the target country (see Appendix 2). The scandal target countries are } \\
\text { identified as China, Spain, and Italy. }\end{array}$ \\
\hline AHaveScandal & $\begin{array}{l}\text { An indicator, which equals one if the acquirer country has undertaken the CGR when the acquisition is announced and some big } \\
\text { business scandals took place in or before the CGR announcement year in the acquirer country (see Appendix 2). The scandal acquirer } \\
\text { countries are identified as Belgium, Australia, France, Germany, Ireland, Netherlands, Sweden, and United States. }\end{array}$ \\
\hline \multicolumn{2}{|c|}{ Panel C: Firm and Deal Variables } \\
\hline SALES/TA_Gr & $\begin{array}{l}\text { The growth rate of sales divided by book value of total assets, winsorized at the } 1 \text { and } 99 \text { percentile. (Source: SDC, Bloomberg, and } \\
\text { WorldScope) }\end{array}$ \\
\hline Firm Size & $\begin{array}{l}\text { Measured as the natural logarithm value of the book value of total assets. The book value of total assets is denominated in } 2000 \text { \$US. } \\
\text { (Source: SDC, Bloomberg, and WorldScope) }\end{array}$ \\
\hline Leverage & $\begin{array}{l}\text { Measured as the total debt (long term }+ \text { short term debt) divided by the book value of total assets. (Source: SDC, Bloomberg, and } \\
\text { WorldScope) }\end{array}$ \\
\hline$M B$ & $\begin{array}{l}\text { Measured as the ratio of the market value of the common equity to the book value of equity; observations with negative } M B s \text { are } \\
\text { replaced by zero. (Source: SDC, Bloomberg, and WorldScope) }\end{array}$ \\
\hline Liquidity & Measured as current assets divided by current liabilities. (Source: SDC, Bloomberg, and WorldScope) \\
\hline Cross List & $\begin{array}{l}\text { An indicator, which is equal to one, if the target firm's listing location is different from its nationality, when the acquisition bid is } \\
\text { announced. (Source: SDC) }\end{array}$ \\
\hline Acquirer Tobin's $Q$ & $\begin{array}{l}\text { Measured as a ratio. The numerator is the book value of total assets subtracting the book value of equity, and then adding the market } \\
\text { value of equity. The denominator is the book value of total assets. All variables are measured in the year prior to the announcement. } \\
\text { (Source: SDC and Compustat) }\end{array}$ \\
\hline Acquirer Firm Size & $\begin{array}{l}\text { Measured as the natural logarithm value of the book value of total assets of U.S. acquirers one year before the announcement of the } \\
\text { acquisition bid. The book value of assets is denominated in } 2000 \text { \$US. (Source: SDC and Compustat) }\end{array}$ \\
\hline Horizontal & An indicator, which is equal to one if the first two-digits of SIC codes for the acquirer and target are the same. (Source: SDC) \\
\hline \multicolumn{2}{|c|}{ Panel D: Other Country-level Variables } \\
\hline GDPPA & $\begin{array}{l}\text { GDP per capita, denominated in } 2000 \text { \$US. (Source: Except Taiwan, the data are taken from the World Development Indicators; for } \\
\text { Taiwan, the data are taken from Global Insights) }\end{array}$ \\
\hline GDPPA Ratio & It is the ratio in GDP per capita between the target and acquirer countries one year prior to the acquisition announcement. \\
\hline Inward FDI/GDP & Net inflows of foreign direct investments as the percent of GDP. \\
\hline Num of Deals & The number of deals taken place in each country during each year in the sample. \\
\hline Crisis1 & $\begin{array}{l}\text { An indicator, which is equal to one if the firm-year observation has any of the following country-year specific combinations: Thailand, } \\
\text { 1997-99; South Korea, 1997-99; Indonesia, 1997-99; Argentina, 2001-02; Brazil, 1998-99; Mexico, 1994-95; Turkey, 1994, and 2000- } \\
\text { 01; Russia, 1998. }\end{array}$ \\
\hline Crisis2 & $\begin{array}{l}\text { An indicator, which is equal to one if the acquisition bid is announced in the following country-year specific combinations: Thailand, } \\
\text { 1997-99; South Korea, 1997-99; Indonesia, 1997-99; Argentina, 2001-02; Brazil, 1998-99; Mexico, 1994-95; Turkey, 1994, and 2000- } \\
\text { 01; Russia, 1998. }\end{array}$ \\
\hline
\end{tabular}


Table 1: Country Distribution of the Sample for Estimating Probit Target Selection Model

This table reports the distribution of the sample for estimating the Probit target selection model. The data are mainly taken from the WorldScope and SDC. Panel A reports country distribution for full, target and non-target sample, respectively. Columns (1), (3) and (5) present the number of firm-year observations of the full-, target-, and non-target sample for each target countries, respectively. Column (2), (4) and (6) present the percentage of firm-year observations of the full-, target-, and non-target sample for each target country, respectively. Target sample includes only the firms that receive acquisition bids from strong-IP countries' acquirers in year $\mathrm{t}+1$. Target and non-target sample are matched by country, year, and industry (defined by the first-two digit SIC codes). Panel B presents country distribution of the sample by acquirer countries, strong-IP target countries, and weak-IP target countries.

\begin{tabular}{|c|c|c|c|c|c|c|}
\hline \multirow[b]{2}{*}{ Target Country } & \multicolumn{2}{|c|}{ Full } & \multicolumn{2}{|c|}{ Target } & \multicolumn{2}{|c|}{ Non-target } \\
\hline & $\mathbf{N}$ & $\%$ & $\mathbf{N}$ & $\%$ & $\mathbf{N}$ & $\%$ \\
\hline & (1) & (2) & (3) & (4) & (5) & (6) \\
\hline Argentina & 3 & 0.03 & 1 & 0.14 & 2 & 0.02 \\
\hline Australia & 756 & 7.89 & 50 & 7.07 & 706 & 7.96 \\
\hline Austria & 22 & 0.23 & 4 & 0.57 & 18 & 0.2 \\
\hline Belgium & 38 & 0.4 & 7 & 0.99 & 31 & 0.35 \\
\hline Brazil & 8 & 0.08 & 1 & 0.14 & 7 & 0.08 \\
\hline Canada & 1,135 & 11.85 & 106 & 14.99 & 1,029 & 11.6 \\
\hline Chile & 7 & 0.07 & 2 & 0.28 & 5 & 0.06 \\
\hline China & 141 & 1.47 & 7 & 0.99 & 134 & 1.51 \\
\hline Czech Republic & 6 & 0.06 & 2 & 0.28 & 4 & 0.05 \\
\hline Denmark & 28 & 0.29 & 7 & 0.99 & 21 & 0.24 \\
\hline Finland & 33 & 0.34 & 9 & 1.27 & 24 & 0.27 \\
\hline France & 537 & 5.61 & 45 & 6.36 & 492 & 5.54 \\
\hline Germany & 673 & 7.03 & 35 & 4.95 & 638 & 7.19 \\
\hline Greece & 15 & 0.16 & 4 & 0.57 & 11 & 0.12 \\
\hline Hong Kong & 120 & 1.25 & 9 & 1.27 & 111 & 1.25 \\
\hline India & 71 & 0.74 & 6 & 0.85 & 65 & 0.73 \\
\hline Indonesia & 27 & 0.28 & 4 & 0.57 & 23 & 0.26 \\
\hline Ireland-Rep & 21 & 0.22 & 7 & 0.99 & 14 & 0.16 \\
\hline Israel & 30 & 0.31 & 6 & 0.85 & 24 & 0.27 \\
\hline Italy & 35 & 0.37 & 5 & 0.71 & 30 & 0.34 \\
\hline Japan & 875 & 9.13 & 17 & 2.4 & 858 & 9.67 \\
\hline Malaysia & 111 & 1.16 & 7 & 0.99 & 104 & 1.17 \\
\hline Mexico & 42 & 0.44 & 8 & 1.13 & 34 & 0.38 \\
\hline Netherlands & 107 & 1.12 & 24 & 3.39 & 83 & 0.94 \\
\hline New Zealand & 23 & 0.24 & 7 & 0.99 & 16 & 0.18 \\
\hline Norway & 99 & 1.03 & 19 & 2.69 & 80 & 0.9 \\
\hline Peru & 4 & 0.04 & 1 & 0.14 & 3 & 0.03 \\
\hline Philippines & 34 & 0.35 & 4 & 0.57 & 30 & 0.34 \\
\hline Poland & 2 & 0.02 & 1 & 0.14 & 1 & 0.01 \\
\hline Russian Fed & 2 & 0.02 & 1 & 0.14 & 1 & 0.01 \\
\hline Singapore & 155 & 1.62 & 16 & 2.26 & 139 & 1.57 \\
\hline South Africa & 52 & 0.54 & 5 & 0.71 & 47 & 0.53 \\
\hline South Korea & 277 & 2.89 & 21 & 2.97 & 256 & 2.89 \\
\hline Spain & 38 & 0.4 & 10 & 1.41 & 28 & 0.32 \\
\hline Sweden & 256 & 2.67 & 31 & 4.38 & 225 & 2.54 \\
\hline Switzerland & 106 & 1.11 & 17 & 2.4 & 89 & 1 \\
\hline Taiwan & 371 & 3.87 & 5 & 0.71 & 366 & 4.12 \\
\hline Thailand & 76 & 0.79 & 11 & 1.56 & 65 & 0.73 \\
\hline Turkey & 2 & 0.02 & 1 & 0.14 & 1 & 0.01 \\
\hline United Kingdom & 3,242 & 33.84 & 184 & 26.03 & 3,058 & 34.46 \\
\hline Total & $\mathbf{9 , 5 8 0}$ & & 707 & $\begin{array}{c}7.38 \% \text { of the } \\
\text { full sample }\end{array}$ & 8,873 & \begin{tabular}{|c|}
$\begin{array}{c}92.62 \% \\
\text { sample }\end{array}$ \\
\end{tabular} \\
\hline
\end{tabular}




\begin{tabular}{|c|c|c|c|c|c|c|c|c|}
\hline \multicolumn{9}{|l|}{ Panel B } \\
\hline \multicolumn{3}{|c|}{ Acquirer Country } & \multicolumn{6}{|c|}{ Target Country } \\
\hline & & & \multicolumn{3}{|c|}{ Weak-IP } & \multicolumn{3}{|c|}{ Strong-IP } \\
\hline & $\mathbf{N}$ & $\%$ & & $\mathbf{N}$ & $\%$ & & $\mathbf{N}$ & $\%$ \\
\hline (1) & $(2)$ & (3) & (4) & (5) & $(6)$ & (7) & (8) & $(9)$ \\
\hline Australia & 20 & 2.83 & Argentina & 3 & 0.23 & Australia & 756 & 9.16 \\
\hline Austria & 4 & 0.57 & Brazil & 8 & 0.6 & Austria & 22 & 0.27 \\
\hline Belgium & 14 & 1.98 & Chile & 7 & 0.53 & Belgium & 38 & 0.46 \\
\hline Canada & 19 & 2.69 & China & 141 & 10.65 & Canada & 1,135 & 13.75 \\
\hline Denmark & 6 & 0.85 & Czech Republic & 6 & 0.45 & Denmark & 28 & 0.34 \\
\hline Finland & 11 & 1.56 & Greece & 15 & 1.13 & Finland & 33 & 0.4 \\
\hline France & 43 & 6.08 & India & 71 & 5.36 & France & 537 & 6.5 \\
\hline Germany & 49 & 6.93 & Indonesia & 27 & 2.04 & Germany & 673 & 8.15 \\
\hline Hong Kong & 11 & 1.56 & Italy & 35 & 2.64 & Hong Kong & 120 & 1.45 \\
\hline Ireland & 8 & 1.13 & Malaysia & 111 & 8.38 & Ireland & 21 & 0.25 \\
\hline Israel & 1 & 0.14 & Mexico & 42 & 3.17 & Israel & 30 & 0.36 \\
\hline Japan & 17 & 2.4 & Peru & 4 & 0.3 & Japan & 875 & 10.6 \\
\hline Netherlands & 25 & 3.54 & Philippines & 34 & 2.57 & Netherlands & 107 & 1.3 \\
\hline New Zealand & 5 & 0.71 & Poland & 2 & 0.15 & New Zealand & 23 & 0.28 \\
\hline Norway & 2 & 0.28 & Russian Fed & 2 & 0.15 & Norway & 99 & 1.2 \\
\hline Singapore & 10 & 1.41 & South Africa & 52 & 3.93 & Singapore & 155 & 1.88 \\
\hline Sweden & 16 & 2.26 & South Korea & 277 & 20.92 & Sweden & 256 & 3.1 \\
\hline Switzerland & 22 & 3.11 & Spain & 38 & 2.87 & Switzerland & 106 & 1.28 \\
\hline United Kingdom & 54 & 7.64 & Taiwan & 371 & 28.02 & United Kingdom & 3,242 & 39.27 \\
\hline United States & 370 & 52.33 & Thailand & 76 & 5.74 & Total & 8,256 & \\
\hline \multirow[t]{2}{*}{ Total } & 707 & & Turkey & 2 & 0.15 & & & \\
\hline & & & Total & 1,324 & & & & \\
\hline
\end{tabular}


Table 2: Statistics of Firm-level Variables Used in Target Selection Regressions

This table reports the statistics of the firm level variables used in Probit target selection regressions. SALES/TA_Gr is the growth rate of sales divided by the book value of total assets. Firm size is measured as the logged value of total assets. Leverage is measured as the total debt (long term + short term debt) divided by the book value of total assets. MB is market to book value, measured as the ratio of the market value of the common equity of the firm to its book value of equity. Observations with negative MB are dropped from the sample. Liquidity is the ratio of the current assets to current liabilities. Crisis1 is an indicator, which is equal to one if the firm-year observation has any of the following country-year combinations: Thailand, 1997-99; South Korea, 1997-99; Indonesia, 1997-99; Argentina, 2001-02; Brazil, 1998-99; Mexico, 1994-95; Turkey, 1994, and 2000-01; Russia, 1998. Panel A, B and C report the statistics of the variables in the full-, target- and non-target sample, respectively.

\begin{tabular}{|c|c|c|c|c|c|c|}
\hline Variable & Obs & Mean & Median & Std. Dev. & Min & Max \\
\hline \multicolumn{7}{|l|}{ Panel A: } \\
\hline SALES/TA_Gr & 9580 & 0.074 & 0.008 & 0.413 & -0.807 & 3.540 \\
\hline Firm Size & 9580 & 5.534 & 5.183 & 2.410 & 0.272 & 11.096 \\
\hline Leverage & 9580 & 0.199 & 0.165 & 0.184 & 0 & 0.995 \\
\hline$M B$ & 9580 & 3.558 & 1.202 & 18.485 & 0 & 835.737 \\
\hline \begin{tabular}{|l} 
Liquidity \\
\end{tabular} & 9580 & 4.139 & 1.660 & 6.054 & 0.156 & 20.390 \\
\hline Crisis1 & 9580 & 0.016 & 0.000 & 0.126 & 0 & 1 \\
\hline \multicolumn{7}{|l|}{ Panel B: } \\
\hline SALES/TA_Gr & 707 & 0.067 & 0.009 & 0.367 & -0.749 & 3.137 \\
\hline Firm Size & 707 & 5.951 & 5.751 & 2.228 & 0.272 & 11.096 \\
\hline Leverage & 707 & 0.272 & 0.225 & 0.235 & 0 & 0.995 \\
\hline$M B$ & 707 & 6.108 & 1.660 & 28.222 & 0 & 429.556 \\
\hline Liquidity & 707 & 4.724 & 1.567 & 6.890 & 0.167 & 20.390 \\
\hline Crisis1 & 707 & 0.033 & 0.000 & 0.178 & 0 & 1 \\
\hline \multicolumn{7}{|l|}{ Panle C: } \\
\hline SALES/TA_Gr & 8873 & 0.074 & 0.007 & 0.416 & -0.807 & 3.540 \\
\hline Firm Size & 8873 & 5.501 & 5.144 & 2.420 & 0.272 & 11.096 \\
\hline Leverage & 8873 & 0.193 & 0.160 & 0.178 & 0 & 0.943 \\
\hline$M B$ & 8873 & 3.355 & 1.132 & 17.464 & 0 & 835.737 \\
\hline Liquidity & 8873 & 4.093 & 1.660 & 5.981 & 0.156 & 20.390 \\
\hline Crisis1 & 8873 & 0.015 & 0.000 & 0.121 & 0 & 1 \\
\hline
\end{tabular}




\section{Table 3: Investor Protection of Host Countries and Cross-border Acquisition Target Selection}

This table reports the results of the Probit target selection regressions. The dependent variable is a binary variable indicating that the firm becomes a target of an acquirer from a strong-IP country in year t; zero otherwise. SALES/TA_Gr is the growth rate of sales divided by the book value of total assets. Firm size is measured as the logged value of total assets. Leverage is measured as the total debt (long term + short term debt) divided by the book value of total assets. $M B$ is market to book value, measured as the ratio of the market value of the common equity of the firm to its book value of equity. Liquidity is the ratio of the current assets to current liabilities. Crisis1 is an indicator, which is equal to one if the firm-year observation has any of the following country-year combinations: Thailand, 1997-99; South Korea, 1997-99; Indonesia, 1997-99; Argentina, 2001-02; Brazil, 1998-99; Mexico, 1994-95; Turkey, 1994, and 2000-01; Russia, 1998. GDPPA is GDP per capita, and denominated in 2000 USD. Inward FDI/GDP is net inflows of foreign direct investments as the percent of GDP. The list of acquirer countries, weak-IP target countries and strong-IP target countries can be found in Panel B of Table 1. The regression coefficients are reported in Column (1) and (3) and the marginal effects of independent variables are reported in Column (2) and (4). The marginal effects are calculated at the mean level. All regressions are estimated with year, industry (defined as the first-two digit SIC codes) and target country fixed effects. Robust standard errors are reported in parentheses. ${ }^{*}, * *$ and $* * *$ indicates significance at the $10 \%, 5 \%$ and $1 \%$, respectively.

\begin{tabular}{|c|c|c|c|c|}
\hline & \multicolumn{4}{|c|}{ Dep Var: Target=1 } \\
\hline & \multicolumn{2}{|c|}{ Weak-IP } & \multicolumn{2}{|c|}{ Strong-IP } \\
\hline & Coefficient & Marginal Effect & Coefficient & Marginal Effect \\
\hline & (1) & $(2)$ & (3) & (4) \\
\hline \multirow[t]{2}{*}{ SALES/TA_Gr } & $0.333 * *$ & $0.028 *$ & 0.013 & 0.001 \\
\hline & $(0.168)$ & & $(0.050)$ & \\
\hline \multirow[t]{2}{*}{ Firm Size } & 0.028 & 0.002 & 0.006 & 0.001 \\
\hline & $(0.051)$ & & $(0.011)$ & \\
\hline \multirow[t]{2}{*}{ Leverage } & $1.922 * * *$ & $0.161 * * *$ & $0.817 * * *$ & $0.090 * * *$ \\
\hline & $(0.336)$ & & $(0.132)$ & \\
\hline \multirow[t]{2}{*}{$M B$} & $1.265 * * *$ & $0.106 * * *$ & 0.002 & 0.000 \\
\hline & $(0.175)$ & & $(0.001)$ & \\
\hline \multirow[t]{2}{*}{\begin{tabular}{|l|} 
Liquidity \\
\end{tabular}} & $0.053^{*}$ & 0.004 & $0.013^{*}$ & $0.001 *$ \\
\hline & $(0.031)$ & & $(0.007)$ & \\
\hline \multirow[t]{2}{*}{ GDPPA } & -0.385 & -0.032 & $0.061 * * *$ & $0.007 * * *$ \\
\hline & $(0.300)$ & & $(0.015)$ & \\
\hline \multirow[t]{2}{*}{ Inward FDI/GDP } & $0.452 * * *$ & $0.038 * *$ & 0.002 & 0.000 \\
\hline & $(0.154)$ & & $(0.006)$ & \\
\hline \multirow[t]{2}{*}{ Crisis1 } & -0.798 & $-0.040 * *$ & & \\
\hline & $(0.537)$ & & & \\
\hline \multirow[t]{2}{*}{ Constant } & 2.431 & & $-2.769 * * *$ & \\
\hline & $(5.978)$ & & $(0.380)$ & \\
\hline \begin{tabular}{|l} 
Observations \\
\end{tabular} & 1324 & & 8256 & \\
\hline Year FE & $\mathrm{Y}$ & & $\mathrm{Y}$ & \\
\hline Industry FE & $\mathrm{Y}$ & & $\mathrm{Y}$ & \\
\hline Country FE & $\mathrm{Y}$ & & $\mathrm{Y}$ & \\
\hline Pseudo R2 & 0.505 & & 0.110 & \\
\hline
\end{tabular}


Table 4: Country Distribution of the Sample for Testing the Impact of CGRs on the Type of Firms being Targeted

This table reports the country distribution of the sample for testing the impact of CGRs on the types of firms being targeted. Panel A and B present the sample distribution by target countries and acquirer countries, respectively. Column (1) \& (2) present the sample distribution of the full sample. Column (3) \& (4) and (5) \& (6) present the sample distribution for pre- and post-CGR of target countries, respectively. Column (7) \& (8) and (9) \& (10) present the sample distribution for pre- and post-CGRs of acquirer countries, respectively.

\begin{tabular}{|c|c|c|c|c|c|c|c|c|c|c|}
\hline \multicolumn{11}{|l|}{ Panel A: } \\
\hline \multirow[t]{2}{*}{ Target Country } & \multicolumn{2}{|c|}{ Full sample } & \multicolumn{2}{|c|}{ Pre-TCGR } & \multicolumn{2}{|c|}{ Post-TCGR } & \multicolumn{2}{|c|}{ Pre-ACGR } & \multicolumn{2}{|c|}{ Post-ACGR } \\
\hline & $\mathbf{N}$ & $\%$ & $\mathbf{N}$ & $\%$ & $\mathbf{N}$ & $\%$ & $\mathbf{N}$ & $\%$ & $\mathbf{N}$ & $\%$ \\
\hline & (1) & $(2)$ & (3) & (4) & (5) & $(6)$ & $(7)$ & (8) & (9) & (10) \\
\hline Argentina & 3 & 1.1 & 3 & 1.46 & 0 & 0 & 3 & 1.4 & 0 & 0 \\
\hline Brazil & 13 & 4.76 & 11 & 5.37 & 2 & 2.94 & 12 & 5.58 & 1 & 1.72 \\
\hline Chile & 4 & 1.47 & 4 & 1.95 & 0 & 0 & 4 & 1.86 & 0 & 0 \\
\hline Czech Republic & 9 & 3.3 & 9 & 4.39 & 0 & 0 & 9 & 4.19 & 0 & 0 \\
\hline Greece & 6 & 2.2 & 6 & 2.93 & 0 & 0 & 4 & 1.86 & 2 & 3.45 \\
\hline India & 11 & 4.03 & 8 & 3.9 & 3 & 4.41 & 6 & 2.79 & 5 & 8.62 \\
\hline Indonesia & 11 & 4.03 & 11 & 5.37 & 0 & 0 & 8 & 3.72 & 3 & 5.17 \\
\hline Italy & 20 & 7.33 & 20 & 9.76 & 0 & 0 & 16 & 7.44 & 4 & 6.9 \\
\hline Philippines & 13 & 4.76 & 13 & 6.34 & 0 & 0 & 13 & 6.05 & 0 & 0 \\
\hline Poland & 10 & 3.66 & 10 & 4.88 & 0 & 0 & 10 & 4.65 & 0 & 0 \\
\hline Russian Fed & 5 & 1.83 & 5 & 2.44 & 0 & 0 & 1 & 0.47 & 4 & 6.9 \\
\hline South Africa & 19 & 6.96 & 19 & 9.27 & 0 & 0 & 16 & 7.44 & 3 & 5.17 \\
\hline South Korea & 31 & 11.36 & 9 & 4.39 & 22 & 32.35 & 27 & 12.56 & 4 & 6.9 \\
\hline Spain & 26 & 9.52 & 22 & 10.73 & 4 & 5.88 & 22 & 10.23 & 4 & 6.9 \\
\hline Taiwan & 13 & 4.76 & 4 & 1.95 & 9 & 13.24 & 5 & 2.33 & 8 & 13.79 \\
\hline Thailand & 20 & 7.33 & 20 & 9.76 & 0 & 0 & 19 & 8.84 & 1 & 1.72 \\
\hline Turkey & 6 & 2.2 & 6 & 2.93 & 0 & 0 & 3 & 1.4 & 3 & 5.17 \\
\hline Total & 273 & & 205 & & 68 & & 215 & & 58 & \\
\hline Canada & 12 & 4.4 & 10 & 4.88 & 2 & 2.94 & 11 & 5.12 & 1 & 1.72 \\
\hline Denmark & 3 & 1.1 & 3 & 1.46 & 0 & 0 & 3 & 1.4 & 0 & 0 \\
\hline Finland & 2 & 0.73 & 2 & 0.98 & 0 & 0 & 1 & 0.47 & 1 & 1.72 \\
\hline France & 29 & 10.62 & 24 & 11.71 & 5 & 7.35 & 20 & 9.3 & 9 & 15.52 \\
\hline Germany & 24 & 8.79 & 15 & 7.32 & 9 & 13.24 & 16 & 7.44 & 8 & 13.79 \\
\hline Hong Kong & 14 & 5.13 & 10 & 4.88 & 4 & 5.88 & 11 & 5.12 & 3 & 5.17 \\
\hline Japan & 21 & 7.69 & 14 & 6.83 & 7 & 10.29 & 21 & 9.77 & 0 & 0 \\
\hline Netherlands & 9 & 3.3 & 9 & 4.39 & 0 & 0 & 8 & 3.72 & 1 & 1.72 \\
\hline Norway & 1 & 0.37 & 1 & 0.49 & 0 & 0 & 1 & 0.47 & 0 & 0 \\
\hline Singapore & 8 & 2.93 & 5 & 2.44 & 3 & 4.41 & 4 & 1.86 & 4 & 6.9 \\
\hline Sweden & 3 & 1.1 & 3 & 1.46 & 0 & 0 & 3 & 1.4 & 0 & 0 \\
\hline Switzerland & 8 & 2.93 & 7 & 3.41 & 1 & 1.47 & 6 & 2.79 & 2 & 3.45 \\
\hline United Kingdom & 41 & 15.02 & 33 & 16.1 & 8 & 11.76 & 31 & 14.42 & 10 & 17.24 \\
\hline United States & 80 & 29.3 & 54 & 26.34 & 26 & 38.24 & 65 & 30.23 & 15 & 25.86 \\
\hline Total & 273 & & 205 & & 68 & & 215 & & 58 & \\
\hline
\end{tabular}




\section{Table 5: Impacts of CGRs on the Type of Firms being Targeted}

This table reports the results of the impact of CGRs on the type of firms being targeted. The dependent variable is SALES/TA_Gr in Columns (1) to (3) and the numerical cumulative density functions (CDFs) of SALES/TA_Gr in Columns (4) and (5). TCGR is an indicator, which is equal to one if an influential CGR (see Appendix 2) has been undertaken in the target country, when the acquisition bid is announced. ACGR is an indicator, which is equal to one if an influential CGR (see Appendix 2) has been undertaken in the acquirer country, when the acquisition bid is announced. Num of Deals is the number of deals taken place in each country during each year in the sample. Horizontal is an indicator, which is equal to one if the acquiring and target firm are sharing the same first two-digits of SIC codes. Cross List is an indicator, which equals one, when the target firm is cross-listed in other country's stock exchange. Crisis2 is an indicator, which is equal to one if the acquisition bid is announced in the following country-year specific combinations: Thailand, 1997-99; South Korea, 1997-99; Indonesia, 1997-99; Argentina, 2001-02; Brazil, 1998-99; Mexico, 1994-95; Turkey, 1994, and 2000-01; Russia, 1998. GDPPA Ratio is the ratio of GDP per Capita between the target and acquirer country. THaveScandal is an indicator, which equals one if the target country has undertaken the CGR when the acquisition is announced and some big business scandals took place in or before the CGR announcement year in the target country (see Appendix 2). The scandal target countries are identified as China, Spain, and Italy. AHaveScandal is an indicator, which equals one if the acquirer country has undertaken the CGR when the acquisition is announced and some big business scandals took place in or before the CGR announcement year in the acquirer country (see Appendix 2). The scandal acquirer countries are identified as Belgium, Australia, France, Germany, Ireland, Netherlands, Sweden, and United States. Acquirer Firm Tobin's Q is measured as a ratio. The numerator is the book value of total assets subtracting the book value of equity, and then adding the market value of equity. The denominator is the book value of total assets. All variables are measured in the year prior to the announcement. Acquirer Firm Size is measured as the book value of assets is denominated in 2000 USD. All variables are measured in one year before the announcements of acquisition bids. Columns (1) to (4) are estimated with the OLS and Column (5) is estimated with a Tobit estimate. All regressions are estimated with year, industry (defined as first-two digit SIC codes), acquirer country, and target country dummies. Robust standard errors are reported in parentheses. *,**, and $* * *$ indicate significance at the $10 \%, 5 \%$ and $1 \%$, respectively.

\begin{tabular}{|c|c|c|c|c|c|}
\hline & \multicolumn{5}{|c|}{ Dependent Variable: SALES/TA_Gr } \\
\hline & \multicolumn{3}{|c|}{ Value } & \multicolumn{2}{|c|}{ CDF } \\
\hline & \multicolumn{4}{|c|}{ OLS } & Tobit \\
\hline & (1) & $(2)$ & (3) & (4) & $(5)$ \\
\hline \multirow[t]{2}{*}{ TCGR } & $-0.275 * *$ & $-0.328 * * *$ & $-0.441 * * *$ & $-0.234 * * *$ & $-0.288 * * *$ \\
\hline & $(0.120)$ & $(0.122)$ & $(0.139)$ & $(0.074)$ & $(0.078)$ \\
\hline \multirow[t]{2}{*}{$A C G R$} & $0.251 *$ & $0.351 * *$ & $0.401 * *$ & $0.223 *$ & $0.232 *$ \\
\hline & $(0.144)$ & $(0.170)$ & $(0.181)$ & $(0.117)$ & $(0.132)$ \\
\hline \multirow[t]{2}{*}{ Cross List } & -0.038 & -0.087 & -0.095 & 0.000 & 0.011 \\
\hline & $(0.119)$ & $(0.119)$ & $(0.137)$ & $(0.072)$ & $(0.082)$ \\
\hline \multirow[t]{2}{*}{ Horizontal } & 0.076 & 0.088 & $0.151 *$ & 0.073 & 0.066 \\
\hline & $(0.085)$ & $(0.084)$ & $(0.090)$ & $(0.057)$ & $(0.059)$ \\
\hline \multirow[t]{2}{*}{ Num of Deals } & -0.016 & -0.018 & -0.047 & $-0.196 * *$ & $-0.216^{* *}$ \\
\hline & $(0.069)$ & $(0.068)$ & $(0.119)$ & $(0.097)$ & $(0.086)$ \\
\hline \multirow[t]{2}{*}{ GDPPA Ratio } & $-0.006 * *$ & $-0.005 *$ & $-0.008 * * *$ & $-0.004 *$ & $-0.005^{* * *}$ \\
\hline & $(0.003)$ & $(0.003)$ & $(0.003)$ & $(0.002)$ & $(0.002)$ \\
\hline \multirow[t]{2}{*}{ Crisis2 } & 0.054 & 0.048 & 0.215 & -0.123 & $-0.167 *$ \\
\hline & $(0.138)$ & $(0.137)$ & $(0.181)$ & $(0.107)$ & $(0.096)$ \\
\hline \multirow[t]{2}{*}{ THaveScandal } & & $0.077 * *$ & 0.032 ** & 0.114 & 0.133 \\
\hline & & $(0.033)$ & $(0.013)$ & $(0.119)$ & $(0.120)$ \\
\hline \multirow[t]{2}{*}{ AHaveScandal } & & -0.196 & 0.018 & -0.079 & -0.073 \\
\hline & & $(0.156)$ & $(0.170)$ & $(0.112)$ & $(0.118)$ \\
\hline \multirow[t]{2}{*}{ Acquirer Firm Size } & & & 0.004 & $0.020^{*}$ & $0.022 *$ \\
\hline & & & $(0.026)$ & $(0.011)$ & $(0.013)$ \\
\hline \multirow[t]{2}{*}{ Acquirer Tobin's $Q$} & & & 0.002 & 0.001 & 0.002 \\
\hline & & & $(0.002)$ & $(0.001)$ & $(0.002)$ \\
\hline \multirow[t]{2}{*}{ Constant } & 0.050 & 0.019 & -0.041 & $0.553 * *$ & 0.607 **** \\
\hline & $(0.220)$ & $(0.218)$ & $(0.465)$ & $(0.222)$ & $(0.211)$ \\
\hline Year dummy & $\mathrm{Y}$ & $\mathrm{Y}$ & $\mathrm{Y}$ & $\mathrm{Y}$ & $\mathrm{Y}$ \\
\hline Industry dummy & $\mathrm{Y}$ & $\mathrm{Y}$ & $\mathrm{Y}$ & $\mathrm{N}$ & $\mathrm{N}$ \\
\hline Target country dummy & $\mathrm{Y}$ & $\mathrm{Y}$ & $\mathrm{Y}$ & $\mathrm{N}$ & $\mathrm{N}$ \\
\hline Acquirer country dummy & $\mathrm{Y}$ & $\mathrm{Y}$ & $\mathrm{Y}$ & $\mathrm{Y}$ & $\mathrm{Y}$ \\
\hline Observations & 273 & 273 & 160 & 121 & 121 \\
\hline$R$-squared (Pseudo R2) & 0.41 & 0.43 & 0.64 & 0.40 & $(0.53)$ \\
\hline
\end{tabular}


Table 6: Timing of Reforms and Confounding Effects

This table reports the results of the impact of CGRs on the type of firms being targeted. The dependent variable is SALES/TA_Gr in Columns (1) to (3) and the numerical cumulative density functions (CDFs) of SALES/TA_Gr in Columns (4) and (5). TCGR_t-3 is equal to one for all years that predate the CGR undertaken by the target country by three or more years and is equal to zero in all other years. TCGR_t+1 is equal to one for all years at least one years after the CGR undertaken by the target country and zero during other years. ACGR_t-3 is equal to one for all years that predate the CGR undertaken by the acquirer country by three or more years and is equal to zero in all other years. ACGR_t +1 is equal to one for all years at least one years after the CGR undertaken by the acquirer country and zero during other years. Num of Deals is the number of deals taken place in each country during each year in the sample. Horizontal is an indicator, which is equal to one if the acquiring and target firm are sharing the same first two-digits of SIC codes. Cross List is an indicator, which equals one, when the target firm is cross-listed in other country's stock exchange. Crisis2 is an indicator, which is equal to one if the acquisition bid is announced in the following country-year specific combinations: Thailand, 1997-99; South Korea, 1997-99; Indonesia, 1997-99; Argentina, 2001-02; Brazil, 1998-99; Mexico, 1994-95; Turkey, 1994, and 2000-01; Russia, 1998. GDPPA Ratio is the ratio of GDP per Capita between the target and acquirer country. THaveScandal is an indicator, which equals one if the target country has undertaken the CGR when the acquisition is announced and some big business scandals took place in or before the CGR announcement year in the target country (see Appendix 2). The scandal target countries are identified as China, Spain, and Italy. AHaveScandal is an indicator, which equals one if the acquirer country has undertaken the CGR when the acquisition is announced and some big business scandals took place in or before the CGR announcement year in the acquirer country (see Appendix 2). The scandal acquirer countries are identified as Belgium, Australia, France, Germany, Ireland, Netherlands, Sweden, and United States. Acquirer Firm Tobin's Q is measured as a ratio. The numerator is the book value of total assets subtracting the book value of equity, and then adding the market value of equity. The denominator is the book value of total assets. All variables are measured in the year prior to the announcement. Acquirer Firm Size is measured as the book value of assets is denominated in 2000 USD. All variables are measured in one year before the announcements of acquisition bids. Columns (1) to (4) are estimated with the OLS and Column (5) is estimated with a Tobit estimate. All regressions are estimated with year, industry (defined as first-two digit SIC codes), acquirer country, and target country dummies. Robust standard errors are reported in parentheses. ${ }^{*},{ }^{*}$, and $* * *$ indicate significance at the $10 \%, 5 \%$ and $1 \%$, respectively.

\begin{tabular}{|c|c|c|}
\hline & \multicolumn{2}{|c|}{ Dependent Variable: SALES/TA_Gr } \\
\hline & (1) & (2) \\
\hline \multirow[t]{2}{*}{$T C G R \_t-2$} & -0.262 & -0.145 \\
\hline & $(0.200)$ & $(0.197)$ \\
\hline \multirow[t]{2}{*}{$T C G R \_t-3$} & -0.108 & -0.182 \\
\hline & $(0.144)$ & $(0.190)$ \\
\hline \multirow[t]{2}{*}{$T C G R \_t$} & $-0.502 * * *$ & $-0.670 * * *$ \\
\hline & $(0.189)$ & $(0.201)$ \\
\hline \multirow[t]{2}{*}{$T C G R \_t+1$} & $-0.403 * * *$ & $-0.349 * *$ \\
\hline & $(0.150)$ & $(0.158)$ \\
\hline \multirow[t]{2}{*}{$A C G R \_t-2$} & $-0.424 * * *$ & -0.264 \\
\hline & $(0.160)$ & $(0.171)$ \\
\hline \multirow[t]{2}{*}{$A C G R \_t-3$} & 0.339 & 0.476 \\
\hline & $(0.299)$ & $(0.319)$ \\
\hline \multirow[t]{2}{*}{$A C G R \_t$} & 0.019 & $0.295^{*}$ \\
\hline & $(0.175)$ & $(0.150)$ \\
\hline \multirow[t]{2}{*}{$A C G R \_t+1$} & $0.608^{*}$ & $0.741 *$ \\
\hline & $(0.338)$ & $(0.384)$ \\
\hline \multirow[t]{2}{*}{ Cross List } & -0.061 & -0.162 \\
\hline & $(0.119)$ & $(0.139)$ \\
\hline \multirow[t]{2}{*}{ Horizontal } & 0.083 & $0.167 *$ \\
\hline & $(0.083)$ & $(0.088)$ \\
\hline \multirow[t]{2}{*}{ Num of Deals } & -0.036 & 0.022 \\
\hline & $(0.068)$ & $(0.120)$ \\
\hline \multirow[t]{2}{*}{ GDPPA Ratio } & -0.003 & -0.005 \\
\hline & $(0.003)$ & $(0.003)$ \\
\hline \multirow[t]{2}{*}{ Crisis } & 0.062 & 0.169 \\
\hline & $(0.142)$ & $(0.190)$ \\
\hline \multirow[t]{2}{*}{ THaveScandal } & $0.083^{*}$ & 0.073 \\
\hline & $(0.049)$ & $(0.239)$ \\
\hline \multirow[t]{2}{*}{ AHaveScandal } & -0.061 & 0.200 \\
\hline & $(0.137)$ & $(0.144)$ \\
\hline \multirow[t]{2}{*}{ Acquirer Firm Size } & & -0.009 \\
\hline & & $(0.028)$ \\
\hline \multirow[t]{2}{*}{ Acquirer Tobin's $Q$} & & 0.002 \\
\hline & & $(0.002)$ \\
\hline \multirow[t]{2}{*}{ Constant } & -0.107 & -0.245 \\
\hline & $(0.362)$ & $(0.467)$ \\
\hline Year dummy & $\mathrm{Y}$ & $\mathrm{Y}$ \\
\hline Industry dummy & $\mathrm{Y}$ & $\mathrm{Y}$ \\
\hline Target country dummy & $\mathrm{Y}$ & $\mathrm{Y}$ \\
\hline Acquirer country dummy & $\mathrm{Y}$ & $\mathrm{Y}$ \\
\hline Observations & 273 & 160 \\
\hline$R$-squared & 0.46 & 0.69 \\
\hline
\end{tabular}




\section{Appendix for Corporate Governance Reforms}

This Appendix contains details of the key features associated with the CGR of each country. The following table summaries the CGR year of each sample country (if the country undertook a CGR) and the compliance level of each CGR. In the section of country details, each CGR is described from the following five perspectives. The first is the general information of corporate governance background of the country, including the motivation of the CGR, important but unsuccessful legislative activities regarding on corporate governance system in the country (if there is any), etc. The second is the general description of the CGR, including the announcement date, effective date, policy makers, general comments of the reform etc. The third is a CGR's major purposes and contents. The fourth is the brief description of supplementary regulatory events or related legislative activities taking place around the same period of the CGR (if there is any). The last is about how to define the CGR year of the country according to the facts and the criteria. Not all countries have complete information. The above is only the basic organization of the description of the CGR of each country, and the details covered for each CGR may vary from country to country.

\begin{tabular}{|c|c|c|c|}
\hline \multirow[t]{2}{*}{ Country } & \multirow[t]{2}{*}{ CGR Year } & \multicolumn{2}{|c|}{ Compliance Level } \\
\hline & & Comply-or-explain & Legal Rule \\
\hline Argentina & 2001 & & $\mathrm{x}$ \\
\hline Australia & 2004 & $\mathrm{x}$ & \\
\hline Austria & 2002 & & $\mathrm{x}$ \\
\hline Belgium & 2005 & $\mathrm{x}$ & \\
\hline Brazil & 2002 & & $\mathrm{x}$ \\
\hline Canada & 2006 & & $\mathrm{x}$ \\
\hline Chile & 2001 & & $\mathrm{x}$ \\
\hline China & 2001 & $\mathrm{x}$ & \\
\hline Finland & 2004 & $\mathrm{x}$ & \\
\hline France & 2003 & & $\mathrm{x}$ \\
\hline Germany & 2002 & $\mathrm{x}$ & \\
\hline Hong Kong & 2005 & $\mathrm{x}$ & \\
\hline India & 2005 & & $\mathrm{x}$ \\
\hline Ireland & 2005 & & $\mathrm{x}$ \\
\hline Italy & 2006 & & $\mathrm{x}$ \\
\hline
\end{tabular}




\begin{tabular}{|l|c|c|c|} 
Malaysia & 2000 & $\mathrm{x}$ & \\
\hline Mexico & 2001 & $\mathrm{x}$ & \\
\hline Netherlands & 2004 & $\mathrm{x}$ & \\
\hline New Zealand & 2004 & $\mathrm{x}$ & \\
\hline Norway & 2005 & $\mathrm{x}$ & \\
\hline Peru & 2005 & $\mathrm{x}$ & \\
\hline Poland & 2002 & $\mathrm{x}$ & \\
\hline Singapore & 2003 & & $\mathrm{x}$ \\
\hline South Korea & 1999 & $\mathrm{x}$ & \\
\hline Spain & 2003 & $\mathrm{x}$ & \\
\hline Sweden & 2005 & $\mathrm{x}$ & $\mathrm{x}$ \\
\hline Switzerland & 2002 & & $\mathrm{x}$ \\
\hline Taiwan & 2002 & $\mathrm{x}$ & \\
\hline Thailand & 2007 & & \\
\hline UK & 2003 & & \\
\hline US & 2004 & & \\
\hline
\end{tabular}

\section{Country Details}

\section{Argentina (2001) (Legal Rule)}

Changes in local economic conditions (e.g., foreign capital flows, moderate growth in domestic capital markets, and the emergence of the institutional investment industry) induced the government to issue new rules to upgrade companies' governance practices to enhance the competitiveness of the Argentine economy.

Decree No. 677/2001 (“Transparency Decree”) has the well-intentioned goal to reform governance of publicly listed firms in Argentina. It was published at the Official Gazette on May, 2001 and officially became effective on June 1, 2001. It sets the legal framework for publicly listed companies.

Decree No. 677/2001 includes a number of governance guidelines and is inspired by international best practices and standards. It governs transparency practices, the public offering regime, illegal actions, and standards. The 2003 OECD report affirms that Decree No. 677/2001 covers several aspects of good corporate governance practices (e.g. 
mandatory tender offers; procedures to ensure that minority shareholders receive a "fair price" in squeeze-outs and de-listings; a majority of independent members in the audit committees; establishment of arbitration courts for the resolution of conflicts; and a greater role for shareholders through increased participation in shareholders meetings.

Following Decree No. 677/2001, the National Securities Commission (CNV), acting in its capacity as the regulatory enforcement authority, issued several regulations on audit committees.

Although Decree No. 677/2001 made only modest progress during the early stage of its implementation because of the 2001 Argentina financial crisis (Chong and Lopez-deSilanes, 2007), ${ }^{1}$ it is considered to be an important indicator of the new regulatory environment in Argentina and has played important roles in guiding publicly listed firms' governance practices (eSTANDARDSFORUM). The CGR year of Argentina is treated to be 2001 when Decree No. 677/2001 officially becomes effective.

\section{References:}

Aguilera, Ruth V., "A Comparative Analysis of Corporate Governance Systems in Latin America: Argentina, Brazil, Chile, Colombia and Venezuela," Corporate Governance in Developing Economies, Forthcoming in McGee, R., Ed., (2008) Springer.

Chong, Alberto, and Florencio Lopez-de-Silanes, Investor Protection and Corporate Governance: Firm-level Evidence across Latin America. (World Bank Publications, 2007, ISBN 082136913X, 9780821369135).

eSTANDARDSFORUM

(http://www.estandardsforum.org/jhtml/country/Argentina/sp/1/6).

Organization for Economic Co-operation and Development, "White paper on Corporate Governance in Latin America," Paris: Organization for Economic Co-operation and Development, 2003. (http://www.oecd.org/dataoecd/25/2/18976210.pdf).

\section{Australia (2004) (Comply-or-explain Rule)}

\footnotetext{
${ }^{1}$ During the 2001 Argentine crisis, firms had no incentives to upgrade their governance practices.
} 
The genesis of Australian CGR was the Ramsay Report of 2001, which proposed the establishment of audit committees in listed companies. However, the report was not fully welcomed by regulators.

Australia had its own share of corporate scandals (e.g., HIH Insurance). ${ }^{2}$ The Commonwealth Government enacted the Corporate Law Economic Reform Program (Audit Reform \& Corporate Disclosure) Act of 2004 (CLERP 9). It contains a number of reforms that safeguard auditor independence, as a response to the Ramsay Report and to the enactment of Sarbanes-Oxley Act of 2002. The CLERP 9 is a comply-or-explain based regulation and became effective on July 1, 2004. It is viewed as the Australian version of Sarbanes-Oxley Act (Wikipedia).

The CLERP 9 includes three bodies: (1) the Financial Reporting Council to oversee standard setting for audit and accounting; (2) the Australian Securities Exchange's (ASX) Corporate Governance Council to oversee the development of best practice guidelines for corporate governance within listed companies; and (3) the Shareholders and Investors Advisory Council to provide a forum for the consideration of retail investors' concerns (Wikipedia).

Additionally, in March 2003, the ASX Corporate Governance Council released the first edition of the Principles of Good Corporate Governance (Principles) and Best Practice Recommendations (Recommendations). They represent the most comprehensive statement of best practices for Australian listed companies and include 10 Principles and 28 Recommendations supporting the Principles. These new rules apply to listed companies and other types of listed entities (e.g., trusts), listed stapled entities, and listed foreign entities. Listed companies must adopt these recommendations or explain why they do not. These changes in reporting requirements apply to the company's first fiscal year commencing after January 1, 2003. Where a company's fiscal year begins on July 1,

\footnotetext{
2 "In Australia, a Royal Commission was established to investigate the fallout of the second largest insurance company in Australia HIH Insurance. One of the findings of the commission was the misrepresentation of earnings by senior executives." (Simplify Financial Compliance with Commercial Cards)
} 
disclosure was required in relation to the financial July 1, 2003 - June 30, 2004 annual report published in 2004.

The CGR year of Australia is treated to be 2004 when the CLERP 9 is enacted and the first edition of the Principles of Good Corporate Governance and Best Practice Recommendations becomes fully effective.

\section{Reference:}

Australian Securities Exchange

(http://www.asx.com.au/supervision/governance/index.htm).

Australian Securities \& Investments Commission

(http://www.asic.gov.au/asic/asic.nsf/byheadline/CLERP+9?openDocument).

He, Liyu, Sue Wright, and Elaine Evans, Does Better Corporate Governance Result in Lower Earnings Management? Keeping Good Companies, Sunday, July 1, 2007.

Simplify Financial Compliance with Commercial Cards

(http://www.acte.org/events/munich07/Presentations/Visa\%20Compliance\%20White\%20

Paper_Oct07.pdf.).

Wikipedia

(http://en.wikipedia.org/wiki/Corporate_Law_Economic_Reform_Program_Act_2004).

Wikipedia (http://en.wikipedia.org/wiki/Sarbanes-Oxley_Act).

\section{Austria (2002) (Legal Rule)}

The CGR in Austria is associated with the development of the Austrian Corporate Governance Code. It was first introduced on October 1, 2002 by the Austrian Working Group for Corporate Governance. It is mandatory for Austrian publicly listed companies. The Code comprises: (1) legal rules under Austrian laws; (2) comply-or-explain rules; and (3) voluntary recommendations. This Code is viewed as a milestone in the drive to develop and invigorate the Austrian capital market by investors and issuers.

The Code has become an indispensable part of Austrian corporate governance system. It aims to strengthen investor confidence. It is based on the provisions of Austrian 
corporation law, securities law, and capital market law, as well as the OECD Corporate Governance Principles. It provides a framework for corporate management and control. It includes equal treatment of all shareholders; transparency; the independence of the supervisory board; open communication between the managing board and supervisory board; avoidance of conflicts of interest by bodies of the corporation; and efficient control by the supervisory board and auditors.

The CGR year of Austria is treated to be 2002 when the Code of Corporate Governance is first introduced in Austria.

\section{References:}

Austrian Code of Corporate Governance

(http://www.ecgi.org/codes/documents/cg_code_en.pdf).

eSTANDARDSFORUM (http://www.estandardsforum.org/jhtml/country/Austria/sp/27/6/).

\section{Belgium (2005) (Comply-or-explain Rule)}

Before the collapse of Enron and WorldCom, Belgium had its own share of corporate scandals (e.g., Lernout \& Hauspie). ${ }^{3}$ In response, the first draft of the Belgian Corporate Governance Code was published on June 18, 2004 by the Corporate Governance Committee (Committee Lippens). The comments on the Code, together with EU Commission initiatives, helped the Committee finalize the Code. On December 9, 2004, the Committee published the updated version of the Code. It applies to all Belgian listed companies and also functions as a reference framework for all other companies. It has a comply-or-explain principle. The Code replaces the 1998 Recommendations on Corporate Governance, which only requires voluntary adoption. The Code entered into force on January 1, 2005. It has widely been considered to bring significant improvements to Belgian Corporate Governance Regime. (eSTANDARDSFORUM)

\footnotetext{
3 "For some time Lernout \& Hauspie was dogged by rumors of financial impropriety, and in early 1999 the Wall Street Journal ran allegations in its Heard on the Street column by Goldman Sachs analyst Robert Smithson, that earnings had been overstated. Further investigation by Wall Street Journal staffer Jesse Eisinger led to the revelation on 8 August 2000 of a major financial scandal involving fictitious transactions in Korea and improper accounting methodologies elsewhere. In April 2001 founders Jo Lernout and Pol Hauspie, as well as former CEO Gaston Bastiaens, were arrested in what is considered one of the largest corporate scandals in history prior to Enron. Lernout \& Hauspie finally went bankrupt on 25 October 2001 after having struggled for a year."(Wikipedia)
} 
The Code provides the corporate governance guidelines. It covers: role and operation of the board of directors; balanced and independent nature of the board of directors; appointment of directors; chairman of the board; training for directors; performance evaluation; re-election of directors; remuneration for directors and managers; board committees; financial reporting/auditing; management organization; shareholder relations; and the annual report.

Additionally, by January 1, 2005, all Belgian listed companies must prepare their consolidated annual accounts (and reports) in accordance with international accounting standards (IAS).

The CGR year of Belgium is treated to be 2005 when the Code becomes effective and IAS is adopted by all Belgian listed companies.

\section{References:}

The Belgian Code on Corporate Governance

(http://www.ecgi.org/codes/documents/bel_code_dec2004_en.pdf).

Clarke, Thomas, International Corporate Governance: A comparative approach, Routledge, ISBN 041532310x, 9780415323109 (2007).

Corporate Governance Committee

(http://www.corporategovernancecommittee.be/en/committee/guidelines/default.aspx). eSTANDARDSFORUM (

http://www.estandardsforum.org/jhtml/country/Belgium/sp/34/6/).

Global Corporate Governance Guide 2004

(http://www.globalcorporategovernance.com/).

Wikipedia (http://en.wikipedia.org/wiki/Lernout_\&_Hauspie).

\section{Brazil (2002) (Legal Rule)}

The issuance of new Corporate Law (Law No. 10303) on October 31, 2001 is considered an important recent CGR in Brazilian financial market (e.g., Gorga, 2006; Black, 
Gledson De Carvalho, and Gorga, 2008). It became effective 120 days after the promulgation. Before the issuance of Law No. 10303, Brazilian companies are subject to Law 6404/76 modified by Law 9457/97. "The 2001 reform of the Corporation Law strengthened minority shareholders' rights and improved standards for disclosure, with improved laws on tag-along rights, de-listing, non-voting shares, election of board members by minority shareholders and private arbitration. The same year, the Sao Paulo Stock Exchange (BOVESPA) launched three new market segments: "the Special Corporate Governance Levels 1 and 2" and the "Novo Mercado" with each market segment requiring progressively stricter standards of corporate governance. So far, the BOVESPA has been successful in attracting listings on the level 2 and Novo Mercado segments, implying improved standards in corporate governance practices." (eSTANDARDSFORUM)

Additionally, in July 2002, the Securities Exchange Commission published its Recommendations on Corporate Governance applying to all listed companies on a comply-or-explain basis.

The CGR year of Brazil is treated to be 2002 when Law No. 10303 becomes effective and the Recommendations on Corporate Governance are published.

\section{Reference:}

Brazilian Institute of Corporate Governance (http://www.ibgc.org.br/Home.aspx).

CVM Recommendations on Corporate Governance

(http://www.ecgi.org/codes/documents/code_june2002_en.pdf).

Black, Bernard S., Antonio Gledson De Carvalho, and Erica Gorga, An Overview of Brazilian Corporate Governance, ECGI - Finance Working Paper No. 206/2008.

Gorga, Erica, 2006, Culture and Corporate Law Reform: A Case Study of Brazil, University of Pennsylvania Journal of International Economic Law, 27 (2006).

eSTANDARDSFORUM (http://www.estandardsforum.org/jhtml/country/Brazil/sp/3/6).

Global Corporate Governance Guide 2004 (http://www.globalcorporategovernance.com/). 


\section{Canada (2006) (Legal Rule)}

On December 9, 2002, the Provincial Government of Ontario, Canada introduced an omnibus bill in the legislature entitled "Keeping the Promise for a Strong Economy Act (Budget Measures), 2002", also called Bill 198. It is known as the Canadian Sarbanes and Oxley Act (CSOX). It came into effect on December 31, 2005 as Part XXIII.1 of the Ontario Securities Act. For Canadian companies, the deadline for full compliance is 2006.

Recent surveys of Canadian companies have revealed that more than half of surveyed Canadian company executives feel the new regulations have a positive impact on senior management's ability to run the company (Wikipedia).

Bill 198 deals with virtually all of the same issues as Sarbanes-Oxley, including auditor independence, audit committee responsibilities, CEO and CFO accountability for financial reporting and internal controls, faster public disclosure, and stiffer penalties for illegal activities.

Additionally, in 2006, the Toronto Stock Exchange (TSE) adopted the Corporate Governance Guide to Good Disclosure.

The CGR year of Canada is treated to be 2006 when Bill 198 fully comes into effect and TSE adopts the Corporate Governance Guide to Good Disclosure.

\section{Reference:}

eSTANDARDSFORUM (http://www.estandardsforum.org/jhtml/country/Canada/sp/4/6/). Simplify Financial Compliance with Commercial Cards (http://www.acte.org/events/munich07/Presentations/Visa\%20Compliance\%20White\%20 Paper_Oct07.pdf).

Wikipedia (http://en.wikipedia.org/wiki/Bill_198).

\section{Chile (2001) (Legal Rule)}


The Securities Market Law (SML) and Corporate Law (CL) govern listed companies in Chile. The main body was passed in 1981 and amended in 1989 and 1994. In December 2000, both laws were overhauled by Law No. 19,705, known as the Corporate Governance Law or Ley de OPA (Ofertas Publicas de Adquisicion). It went into effect on December 20, 2000. It marks a new milestone in the road of corporate governance development of the securities market in Chile and brings the Chilean corporate legal framework close to international standards. (Escobar, 2001)

Law 19,705 aims to improve fairness, transparency and order in the Chilean capital market. It attempts to regulate corporate governance in two main fields: prices for the sale of a company's shares and rent extraction from controllers. It includes the establishment of a tender offer mandatory procedure; the audit committee; a derivative action to defend the interest of the company; stricter rules on related transactions, and the reinforcement of institutional investors. One of the major innovations of Law 19,705 is the creation of a directors committee in open stock corporations, as established in most codes of best practice and guidelines of corporate governance in many countries.

Subsequent to the enactment of Law 19,705, several complementary regulations have been issued by the Superintendence of Securities and Insurance (SVS), stating precisely how the new legislation should be understood and how it shall be encouraged, controlled, and enforced by the SVS itself.

The CGR year of Chile is treated to be 2001 when the first effects of the new rules introduced by Law 19,705 are observed.

\section{Reference:}

Agosin, Manuel R., and Ernesto Pasten H., Corporate governance in Chile, Central Bank of Chile Working Papers No 209 (2003).

Escobar, Ricardo, Corporate Governance in Chile: New Developments, 2001 (http://www.oecd.org/dataoecd/3/49/1823372.pdf).

World Bank Report on the Observance of Standards and Codes (ROSC) ( 
http://www.worldbank.org/ifa/rosc_chlcg.pdf.)

\section{China (2001) (Comply-or-explain Rule)}

The corporate scandals (e.g., Yin Guang Xia scandal ${ }^{4}$ ) and capital flight cases in mid2001 prompted officials at China Securities Regulatory Commission (CSRC) and other state regulatory bodies to put corporate governance at the top of their list of priorities.

On January 7, 2001, the CSRC and the State Economic and Trade Commission issued the Code of Corporate Governance for Listed Companies in China, also called Zhenjianfa No.1. of 2002. It applies to all listed companies and is based on the comply-or-explain principle. It became effective on the date of issuance. This is the first such code in China. It has strictly followed the OECD Principles of Corporate Governance, indicating that the authorities have sought to bring Chinese corporate governance standards in line with international best practices (eSTANDARDSFORUM).

Using the U.S. legal and regulatory systems as the model, the new code aims to introduce solid corporate governance in listed companies by elevating requirements on accounting procedures and information disclosure, introducing independent directors' systems, and tightening the supervision of corporate management. The Code stipulates the rights and responsibilities of shareholders, directors, the management, stakeholders, and information disclosure. It pays special attention to the protection of investors, especially small investors and prohibits expropriation of minority shareholders' wealth by controlling shareholders.

Additionally, the CSRC published guidelines for introducing independent directors to the board of directors in listed companies in August 2001. It requires each listed company to have at least one-third of the board to be independent directors by June 2003.

\footnotetext{
${ }^{4}$ China experienced its own version of Enron before the corporate scandals took place in the U.S. In July 2001, a blue-chip high-tech company, Yin Guang Xia, was found to have forged customs receipts and made up profit figures in order to support its extremely high and rising stock price. Since then, a few other blue chip companies were also found to have falsified accounts and disclosed misleading financial information. Yin Guang Xia is viewed as Chinese Enron.
} 
The CGR year of China is treated to be 2001 when the Code of Corporate Governance is enacted and the CSRC published guidelines for independent directors of listed companies.

\section{Reference:}

China Securities Regulatory Commission

(http://www.csrc.gov.cn/n575458/n4001948/n4002030/4062964.html).

eSTANDARDSFORUM (http://www.estandardsforum.org/jhtml/country/China/sp/5/6/).

Kang, Yong, Lu Shi, Elizabeth D. Brown, Chinese Corporate Governance: History and

Institutional Framework, RAND center for corporate ethics and governance (2008) (http://www.rand.org/pubs/technical_reports/2008/RAND_TR618.pdf).

Simplify Financial Compliance with Commercial Cards

(http://www.acte.org/events/munich07/Presentations/Visa\%20Compliance\%20White\%20 Paper_Oct07.pdf).

\section{Finland (2004) (Comply-or-explain Rule)}

The implementation of the Corporate Governance Code and the Reform of the Finnish Companies Act had significant influence on corporate governance issues in Finnish law.

HEX Plc, the Central Chamber of Commerce of Finland, and the Confederation of Finnish Industry and Employers appointed a working group on February 17, 2003 to clarify the need to review 1997 corporate governance recommendations and adopted a new Corporate Governance Code for listed companies. The Code has the comply-orexplain principle. It entered into force on July 1, 2004. It increases operational transparency and improves the quality of disclosure.

The Code includes the key issues on general shareholder meeting, supervisory board, board committees, managing directors, other management, compensation, internal control, risk management and internal audit, insider administration, external audit, and communication and disclosure. 
Additionally, the working group appointed by the Ministry of Justice issued its proposal on May 6, 2003 and revised the Companies Act. The new Limited Liabilities Companies Act entered into force on September 1, 2006, replacing the Limited Liabilities Companies Act of 1978. The new Act was designed to strengthen the legal protection of creditors and minority shareholders.

Since both events play significant roles in improving corporate governance in Finland, the one with earlier effective date (i.e. the implementation of the Corporate Governance Code) is treated as the CGR in Finland. The CGR year in Finland is thus treated to be 2004 when the Code enters into force.

\section{Reference:}

eSTANDARDSFORUM (http://www.estandardsforum.org/jhtml/country/Finland/sp/73/6).

Global Corporate Governance Guide 2004

(http://www.globalcorporategovernance.com/).

Corporate Governance Recommendation for Listed Companies

(http://www.ecgi.org/codes/documents/recommendation_en_final.pdf).

\section{France (2003) (Legal Rule)}

The French market was rocked by several scandals in 2002 (e.g., accounting scandal at Vivendi) ${ }^{5}$. These scandals raised the legislator's awareness of issues on French corporate governance.

The Financial Security Law of France (known in France as LSF or Loi de sécurité financière), was adopted by the French Parliament on July 17, 2003 to strengthen the legal provisions on corporate governance. It was published in OJ No. 177, August 2, 2003. It is a rule-based regulation and viewed as French Sarbanes-Oxley Act (Wikipedia).

\footnotetext{
${ }^{5}$ This is an Enron-type scandal. Vivendi had tried to add 1.5bn euros to its 2001 accounts as part of a complex transaction involving shares in BSkyB. Vivendi's efforts to distort its accounts failed after French regulators halted the move. (Hahn, 2005)
} 
Similar to the Sarbanes-Oxley Act, the Financial Security Law of France rests mainly on: increased responsibility of leaders, strengthening internal control, and reducing potential sources of conflicts of interest (Wikipedia). It deals with the following areas: (1) modernization of the authorities supervising financial activities; (2) reinforcement of investor protection; and (3) modernization of the auditing of company accounts and improvement of corporate transparency.

The CGR year in France is treated to be 2003 when the Financial Security Law of France is enacted.

\section{Reference:}

The Corporate Governance of Listed Corporate

(http://www.ecgi.org/codes/documents/cg_oct03_en.pdf).

Lee, Soo H., and Taeyoung Yoo, "Competing Rationales for Corporate Governance in France: Institutional Complementarities between Financial Markets and Innovation Systems," Journal Compilation, 16 (2008).

Hahn, Robert W., “Getting Corporate Governance Right," Wall Street Journal Europe, 23 March, 2005.

Recent Law on Financial Security Improves Corporate Governance in France, by Winston \& Strawn LLP (http://library.findlaw.com/2004/Mar/25/133360.html).

Simplify Financial Compliance with Commercial Cards

(http://www.acte.org/events/munich07/Presentations/Visa\%20Compliance\%20White\%20 Paper_Oct07.pdf).

Wikipedia (http://en.wikipedia.org/wiki/Financial_Security_Law_of_France).

Wikipedia (http://en.wikipedia.org/wiki/Sarbanes-Oxley_Act).

\section{Germany (2002) (Comply-or-explain Rule)}

Long before the collapse of Enron and WorldCom, Germany had its own share of corporate scandals (e.g., Leo Kirch). ${ }^{6}$ In response to these scandals and to address the

\footnotetext{
6 "Leo Kirch and former Chancellor of Germany Helmut Kohl have been on friendly terms for decades. Kirch was always accused of preferential coverage and advertising. Kohl arranged the creation of commercial television as one of his first official acts as Chancellor in 1982, which allowed Kirch to own a TV station and sports broadcasting rights. During the 1999 CDU contributions scandal, it was revealed that Kirch had donated six million DM to the CDU during Helmut Kohl's tenure as Chancellor. In addition,
} 
international community's criticisms on German corporate governance (e.g., inadequate focus on shareholder interests; the two-tier system of executive board and supervisory board; inadequate transparency of German corporate governance; inadequate independence of German supervisory boards; limited independence of auditors), in September 2001, the German Federal Minister of Justice established the governmental commission, which published the initial version of the German Corporate Governance Code in February 2002. The code has a comply-or-explain basis and entered into force on July 26, 2002. German Corporate Governance Code has been viewed as an important Corporate Law Reform (Noack and Zetzsche, 2004; Clarke, 2007). It is viewed to be German version of the Sarbanes-Oxley Act (Wikipedia).

The aim of the Code is to make German corporate governance rules transparent for both national and international investors, thus to strengthen confidence in the management of German corporations. The key sections of the Code are shareholders and the general meeting cooperation between management board and supervisory board; management board; supervisory board; transparency; and reporting and audit of the annual financial statements.

The CGR year of Germany is treated to be 2002 when the Code becomes effective.

\section{Reference:}

Clarke, Thomas, International Corporate Governance: A comparative approach, Routledge, ISBN 041532310x, 9780415323109 (2007).

The Commission of the German Corporate Governance Code (http://www.corporategovernance-code.de/index-e.html).

Noack, Ulrich and Dirk A. Zetzsche, "Corporate Governance Reform in Germany: The Second Decade," European Business Law Review, 16 (2004), PP. 1033-1064.

Simplify Financial Compliance with Commercial Cards

(http://www.acte.org/events/munich07/Presentations/Visa\%20Compliance\%20White\%20 Paper_Oct07.pdf).

Kohl, along with various other CDU/CSU politicians, was revealed to be an adviser to the firm during the insolvency process."( Wikipedia, the free encyclopedia) 
Wikipedia (http://en.wikipedia.org/wiki/Sarbanes-Oxley_Act).

\section{Hong Kong (2005) (Comply-or-explain Rule)}

As a former British dependent territory, Hong Kong's company law and accounting systems were built on a British model. The overall standard of corporate governance has been well regarded. However, the series of U.S. corporate scandals reminded supervisory authorities in Hong Kong to push proactively for reform in corporate governance.

On January 30, 2004, Hong Kong Exchanges and Clearing Limited published the Exposure of Draft Code on Corporate Governance Practices and Corporate Governance Report (the Exposure Paper) replacing the 1993 Code of Best Practice. The Exposure Paper was benchmarked against the best prevailing market practices and international standards, and has a comply-or-explain basis. HKEX enacted the new Code in 2005. The CGR year of Hong Kong is treated to be 2005 when the Code becomes effective.

\section{Reference:}

Clarke, Thomas, International Corporate Governance: A comparative approach, Routledge, ISBN 041532310x, 9780415323109 (2007).

Conclusions on exposure of draft code on corporate governance practices and corporate governance report November 2004

(http://www.ecgi.org/codes/documents/hk_cg_codes_conclusions.pdf). ESTANDARDSFORUM (http://www.estandardsforum.org/jhtml/country/Hong\%20Kong\%20SAR/sp/192/6/). Hong Kong: Corporate Governance Guide, by Deacons, Provided by World Service Group (http://www.hg.org/articles/article_444.html).

Simplify Financial Compliance with Commercial Cards

(http://www.acte.org/events/munich07/Presentations/Visa\%20Compliance\%20White\%20 Paper_Oct07.pdf).

\section{India (2005) (Legal Rule)}


By the mid-1990s, Indian firms began to seek capital to finance expansion into the market spaces created by liberalization and the growth of outsourcing. This led to the need for a CGR in India. The first major step was taken by the Confederation of Indian Industry (CII). CII promulgated a voluntary Corporate Governance Code in 1998. But it was an insufficient regulation. A year later (i.e. 1999), Securities and Exchange Board of India (SEBI) announced a CGR of the Kumar Mangalam Birla Committee (KMBC Report). This became "Clause 49." Clause 49 is based on the 1998 proposed Code of corporate Governance, sponsored by the CII. Clause 49 is viewed as a watershed event in Indian corporate governance by existing studies (e.g., Black and Khanna, 2007; Clarke, 2007; Dharmapala and Khanna, 2008).

Clause 49 contained both requirements and recommendations. "Clause 49 involved prescribing minimum percentages of independent directors (50\% or 33\% depending on whether the Chairman was an executive director) and providing a fairly stringent definition of “independence”. It mandated the number of meetings per year, expected boards to develop a code of conduct and imposed limits on the number of directorships a director could simultaneously hold. It enhanced the power of the audit committee by requiring financial literacy, experience and independence of its members, and by expanding the scope of activities on which the audit committee had oversight. Executives were also expected to be more personally involved in corporate affairs as seen by the requirements for certification by the $\mathrm{CEO}$ and $\mathrm{CFO}$ of financials and overall responsibility for internal controls. This was combined with considerably enhanced disclosure obligations (on many things including accounting treatment and related party transactions) and enhanced requirements for holding companies when overseeing their subsidiaries. These series of changes appear aimed at making Boards and Audit Committees more independent, powerful and focused monitors of management. Moreover, the enhanced disclosures would aid institutional and foreign investors in monitoring management as well." (Black and Khanna, 2007) 
Firms that do not meet these requirements can be de-listed and also given financial penalties. Implementation of Clause 49 was staggered. ${ }^{7}$ It is mandatory for all listed companies to comply with the Clause 49 by December 31, 2005. The CGR year of India is thus treated to be 2005 when Clause 49 completely comes into effect.

\section{Reference:}

Clarke, Thomas, International Corporate Governance: A comparative approach, Routledge, ISBN 041532310x, 9780415323109 (2007).

Black, Bernard S. and Vikramaditya Khanna, "Can Corporate Governance Reforms Increase Firms' Market Values: Event Study Evidence from India," ECGI Working paper series in Finance No. 159/2007.

Dharmapala, Dhammika and Vikramaditya Khanna, "Corporate Governance, Enforcement, and Firm Value: Evidence from India," Working paper (2008).

The draft report of the committee appointed by the SEBI on Corporate Governance under the Chairmanship of Shri Kumar Mangalam Birla (http://www.ecgi.org/codes/documents/draft_report.pdf).

Securities and Exchange Board of India (http://www.sebi.gov.in/).

\section{Ireland (2005) (Legal Rule)}

In Ireland, domestic scandals led to the Companies (Auditing and Accounting) Act, 2003 (the 2003 Act). The 2003 Act was signed by the President on December 23, 2003. It came into force on January 1, 2005. It is considered one of the most significant Irish company law initiatives of the past ten years. Essentially, this is Ireland's Sarbanes-Oxley Act (Global Corporate Governance Guide 2004).

Key Provisions of the 2003 Act include: extension of directors' responsibilities and liability; directors' compliance statements; audit committee; disclosures in accounts; extension of auditors' obligation vis-à-vis the director of corporate enforcement; establishment of Irish auditing and accounting supervisory authority (IAASA); and audit

\footnotetext{
${ }^{7}$ Large firms were required to comply first, followed by medium-sized firms (compliance required in 2002), and then small firms (initially required to comply in 2003, compliance with principle requirements later deterred to 2005). Very small firms were exempted altogether.
} 
exemption. All of these provisions carry criminal penalties for default, including personal penalties applicable to directors.

The CGR year of Ireland is treated to be 2005 when the rule becomes effective.

\section{Reference:}

Companies (Auditing and Accounting) Act, 2003 by Leonora Malone

(http://www.efc.ie/publications/legal_updates/articles/corpbank/companies_(auditing_an d_accounting)_act_2003.html).

Ireland's Sarbanes-Oxley: The Companies (Auditing and Accounting) Act 2003

(http://corporatecompliance.org/Content/NavigationMenu/Resources/International/Irelan d/IAASA_APRIL2004.pdf).

Global Corporate Governance Guide 2004

(http://www.globalcorporategovernance.com/).

\section{Italy (2006) (Legal Rule)}

Although Italy is one of G7 countries, Italian corporate governance is generally considered to have limited legal protection for investors, poor enforcement of legislation, underdeveloped equity markets, pyramidal groups, and high ownership concentration (eSTANDARSFORUM). Italian corporate governance evolution is complicated. It includes Legislative Decree No. 58 of 1998 (Consolidated Law on Financial Intermediation); Decree-Law 6/2003; and the Law on Savings No. 262 of 2005 (Savings Law).

The enactment of the Savings Law is treated to be the CGR in Italy for the following reasons. The Savings Law introduces amendments to the Legislative Decree 58 of 1998 and covers significantly broader scope than the Legislative Decree 58 of 1998. DecreeLaw 6/2003 introduced reforms to Italy's corporate governance rules by mainly focusing on giving Italian companies greater flexibility in their organizational structure by allowing them to select a unitary board, a two-tier board, or the traditional Italian model. However, the IMF report noted that, to date, virtually all listed companies continued to 
follow the traditional Italian model (eSTANDARDSFORUM). In response to the Italian corporate scandals (e.g. Parmalat scandal during 2003-2004) ${ }^{8}$ and legislation recently enacted in other countries to improve corporate governance, increase transparency, and enhance consumer protection, the Savings Law was enacted on January 12, 2006 ${ }^{9}$. It is considered the Italian equivalent of Sarbanes-Oxley Act (Wikipedia). It is more internationally comparable with CGRs in other countries than Legislative Decree No. 58 of 1998 and Decree-Law 6/2003.

The Savings Law amended the Legislative Decree 58 of 1998 on the following issues: the appointment and composition of board of directors; statutory auditors and similar controlling bodies; action against directors; protecting minority shareholders; disclosure of off-shore business; voting rights of banking foundations; conflicts of interest between banks and companies; conflicts of interest in the management of investment funds; conflicts of interest in offering investment services; offers to the public of financial instruments addressed to professional investors; prospectus directive; protection of investors, financial sales representatives and regulated markets, and the duty to provide information; stock option plans; auditing activity; central bank of Italy's structure and powers and co-operation among different authorities; protective measures for investors; corporate crime and sanctions; and transitional provisions. (Italian Law on Savings)

Additionally, a new Corporate Governance Code was promulgated by the Italian Stock Exchange (Borsa Italiana) in March 2006 to strengthen corporate governance among listed companies. The new Code has a comply-or-explain basis. It replaced the Preda Code, which is voluntary for Italian listed companies.

\footnotetext{
${ }^{8}$ Parmalat SpA (BIT: PLT), is a multinational Italian dairy and food corporation and is considered the Italian Enron. The leading global company in the production of UHT (Ultra High Temperature) milk, the company collapsed in 2003 with a 14bn euro (\$20bn; $£ 13 \mathrm{bn}$ ) hole in its accounts. It remains Europe's biggest bankruptcy. The massive financial scandal involving Parmalat, underscored the fact that corporate fraud is not only an American problem. With the disappearance of more than $\$ 10$ billion in declared assets, the scandal is not only one of the largest in corporate history, but it also calls into question how accounting practices, both foreign and domestic, may have contributed to the company's downfall. In December, it was discovered that Parmalat had been using its assets to offset more than a decade's worth of liabilities through a network of offshore and foreign finance companies. The problem, however, was that these assets did not exist. A comedy of errors followed as company representatives scrambled to account for the missing assets. A document from the Bank of America that was supposed to confirm the presence of a valid account containing more than $\$ 4$ billion was instead determined to be a forgery. A Parmalat representative then claimed to have traced $\$ 7.7$ billion to another Bank of America account, but a resulting search by the bank's representatives determined that this account, too, did not exist. This money, like Parmalat's entire profit history, may prove to be a product of the imagination. (Wikipedia; Edmondson, 2004)

${ }^{9}$ The Act generally took effect on January 12, 2006, except for certain provisions, including those that require amendments to a company's organizational documents or further rule-making by the National Commission for Listed Companies and Stock Exchange (CONSOB), the Italian securities regulator, or other administrative bodies.
} 
The CGR year of Italy is treated to be 2006 when the Savings Law becomes effective and the new Corporate Governance Code is promulgated.

\section{Reference:}

Bianchi, Marcello and Luca Enriques, "Corporate Governance in Italy after the 1998 Reform: What Role for Institutional Investors?” Working paper N.43-GENNAIO 2001. Committee for the Corporate Governance of Listed Companies, Code of Conduct (Preda Code), 1999 - Comitato per la Corporate Governance delle Società Quotate, Codice di Autodisciplina, 1999 (http://www.ecgi.org/codes/documents/code_of_conduct.pdf)

Corporate Governance Code, 2006 - Codice di Autodisciplina, 2006

(http://www.ecgi.org/codes/documents/codiceautodisciplina_en.pdf)

Edmondson, Gail, “How Parmalat Went Sour”, business.com, 12 January, 2004. eSTANDARDSFORUM (http://www.estandardsforum.org/jhtml/country/Italy/sp/10/6).

Italian Law on Savings (http://www.freshfields.com/publications/pdfs/2006/13914.pdf).

Wikipedia (http://en.wikipedia.org/wiki/Parmalat).

Wikipedia (http://en.wikipedia.org/wiki/Sarbanes-Oxley_Act).

\section{Malaysia (2000) (Comply-or-explain Rule)}

The 1997 Asian financial crisis made clear the need to enhance the standards of corporate governance in Malaysia to promote stronger, more responsible, transparent and accountable management in the line with international best practices.

On March 24, 1998, the minister of finance announced the establishment of a high-level finance committee. The committee's subsequent report to the ministry resulted in the introduction of the Malaysian Code on Corporate Governance and the establishment of the Minority Shareholders Watchdog Group, a body set up to spearhead shareholder activism and combat abuses by insiders against the minority shareholders (Global corporate governance guide 2004). The Securities Commission of Malaysia issued its Code on Corporate Governance in March 2000, marking a significant milestone in corporate governance reform. The mandatory reporting of compliance with the Code has 
enabled shareholders and the public to assess and determine the standards of corporate governance by listed companies. The Code has a comply-or-explain principle. It is considered an important reform of corporate governance in Malaysia by previous studies (e.g., Abdul Hadi bin Zulkafli, M.Fazilah bt. Abdul Samad, and Md Ishak Ismail).

The Code codified the principles and best practices of good governance and described optimal corporate governance structures and internal processes. It focuses on four areas: board of directors; directors' remuneration; shareholders and accountability; and audit.

The effective year of the Code is not clear, so the CGR year of Malaysia is treated to be 2000 when the Code is issued by the Securities Commission of Malaysia. The results are robust if the CGR year is treated to be 2001 .

\section{Reference:}

Abdul Hadi bin Zulkafli, M.Fazilah bt. Abdul Samad, and Md Ishak Ismail, "Corporate Governance in Malaysia," Working paper.

Clarke, Thomas, "International Corporate Governance: A comparative approach," Routledge, ISBN 041532310x, 9780415323109 (2007).

Global corporate governance guide 2004

(http://www.globalcorporategovernance.com/n_ap/299_305.htm).

Khoo, Boo Yeang, "Corporate Governance in Malaysia, Review of Corporate Governance in Asia," Working paper (2003).

Malaysian Code on Corporate Governance, March 2000

(http://www.ecgi.org/codes/documents/mccg_mar2000.pdf).

Securities Commission, Malaysia (http://www.sc.com.my/).

\section{Mexico (2001) (Legal Rule)}

In June 1999, the Code of Business Best Practices was published, incorporating the basic principles of corporate governance generally recognised in the United States and Europe. Although the degree of compliance must be disclosed annually to the competent 
authorities, compliance of the code is voluntary for companies listed on the Mexican stock exchange. (Global Corporate Governance Guide 2004)

In Mexico, the two key laws affecting corporate governance are the Company Law (Ley General de Sociedades Mercantiles, or LGSM), and the Securities Market Law (Ley del Mercado de Valores, or LMV), which regulates public companies and were introduced in 1975. (eSTANDARDSFORUM) Thus, a major amendment of the LMV in June 2001 is treated to be the most relevant CGR of Mexico. This amendment adopts the standard corporate governance provisions of other leading markets around the world. (Global Corporate Governance Guide 2004) Transparency of listed companies has been greatly improved after enacting the LMV of 2001. (Price III, Roman, and Rountree, 2007)

The amended LMV provides a number of minority rights that must be incorporated into the by-laws of publicly listed companies. They include: the board of directors must be composed of no less than five and not more than 20 members, of which at least $25 \%$ must be independent member; an audit committee composed of members of the board of directors must be established, of which the chairman and the majority of its members must be independent directors. Among other duties, the audit committee must deliver an annual report to the board of directors, and must render an option on certain proposed transactions of the corporation with related parties; and minority shareholders representing stated percentages are entitled, among other rights, to call shareholders meetings, appoint directors, and initiate court actions against directors. (International Financial Law Review)

The CGR year of Mexico is treated to be 2001 when the major amendments of the LMV went into effect.

\section{Reference:}

eSTANDARDSFORUM (http://www.estandardsforum.org/jhtml/country/Mexico/sp/13/6/). Global Corporate Governance Guide 2004 (http://www.globalcorporategovernance.com/). 
International Financial Law Review (http://www.iflr.com/Article/1984906/Mexicoupdates-securities-regulation.html).

Price III, Richard A., Francisco J. Roman, and Brian Rountree, "Governance Reform and Transparency: The Case of Mexico", SSRN Working paper, 2007.

\section{Netherlands (2004) (Comply-or-explain Rule)}

The first corporate governance committee, the Peters Committee, was an initiative of representatives from the Association of Securities Issuing Companies and Amsterdam Stock Exchange. The committee published forty recommendations in 1997 and initiated a public corporate governance debate to introduce the best practice provisions and to improve board practices. But the 1997 Peters Report only requires a voluntary adoption of best practice standards and disclosure.

Netherlands experienced its own share of corporate scandals (e.g., Ahold). ${ }^{10}$ In response, the second corporate governance committee published the Tabaksblat Code in 2003. This code was an initiative of the Ministry of Finance and Economic Affairs. Its scope was wider and aimed at legislative changes. It became effective on January 1, 2004. The Code applies to listed companies and has the comply-or-explain principle.

The Code has five sections: (1) the management board; (2) the supervisory board; (3) the shareholders and general meeting of shareholders; (4) the audit of the financial reporting; and (5) the position of the internal auditor function and the external auditor. Its main purpose is to improve the corporate governance system by providing principle-based best practice.

The CGR year of Netherlands is treated to be 2004 when the Code becomes effective.

\section{Reference:}

\footnotetext{
10، The Ahold scandal became public in February 2003, when the company announced that a series of accounting irregularities had overstated more than $\$ 500$ million in profit booked in the previous two years (i.e. 2001 and 2002). Subsequent disclosures revealed that Ahold's publicly reported earnings overall had been overstated by more than $\$ 1$ billion and that prior revenue had been overstated by \$24 billion.” (Ahold Settles Lawsuit for \$1.1 Billion: Giant Food's Parent Resolves Securities Fraud Class Action)
} 
Bezemer, Pieter-Jan, Gregory F. Maassen, Frans A. J. Van den Bosch, and Henk W. Volberda, Investigating the Development of the Internal and External Service Tasks of Non-executive Directors: The Case of the Netherlands (1997-2005), Corporate Governance: An International Review, 15 (2007), PP. 1119 - 1129.

Clarke, Thomas, International Corporate Governance: A comparative approach, Routledge, ISBN 041532310x, 9780415323109, 2007.

Corporate Governance in the Netherlands

(http://www.mazars.com/news/corporate_governance_nl.php).

Global Corporate Governance Guide 2004

(http://www.globalcorporategovernance.com/).

Starkman, Dean, “Ahold Settles Lawsuit for \$1.1 Billion _ Giant Food's Parent Resolves Securities Fraud Class Action,” Washington Post Staff Writer, November 29, 2005; PP. D03 (http://www.washingtonpost.com/wpdyn/content/article/2005/11/28/AR2005112800144.html).

\section{New Zealand (2004) (Comply-or-explain Rule)}

In 2004, the Corporate Governance Best Practice Code and amendments incorporating corporate governance regulation into the New Zealand Exchange (NZE) Listing Rules entered into force. The Code ensures the autonomy of boards and auditing committees. Amended Listing Rules adopted a comply-or-explain approach.

Additionally, in 2004, the New Zealand Securities Commission (SEC) published Corporate Governance in New Zealand: Principles and Guidelines, consisting of nine principles and guidelines for maintaining a high standard of corporate governance. Since then, the SEC's 2005 and 2006 Annual Reports indicate that it has worked to improve and monitor companies reporting of the corporate governance principles. The principles do not introduce new laws and regulations but are consistent with the NZX Corporate Governance Best Practice Code and the Listing Rules. They apply to listed issuers, other issuers, state-owned enterprises (SOEs), community trusts, and public sector entities, with a particular focus on publicly owned entities. The Commission recognizes that not all of the principles fully apply to all those entities, but expects the entities to follow the 
principles as well. The nine principles deal with issues relating to the right and duties of the board.

The CGR year of New Zealand is treated to be 2004 when the Corporate Governance Best Practice Code and amendments incorporating corporate governance regulation into the NZE Listing Rules entered into force and the Principles and Guidelines of Corporate Governance in New Zealand are published.

\section{Reference:}

Corporate Governance in New Zealand Principles and Guidelines, A Handbook for

Directors, Executives, and Advisers

(http://www.ecgi.org/codes/documents/cg_handbook2004.pdf).

ESTANDARDSFORUM

(http://www.estandardsforum.org/jhtml/country/New\%20Zealand/sp/130/6/).

\section{Norway (2005) (Comply-or-explain Rule)}

The Norwegian Code of Practice for Corporate Governance is based on the provisional national code of practice for corporate governance published in December 2003. The provisional code was the subject of wide consultation, with a deadline of May 30, 2004 for responses from companies and other interested parties. This helped to form the basis for the publication of the Norwegian Code of Practice for Corporate Governance dated December 7, 2004. The English version was prepared by the Norwegian Shareholders Association Norwegian Institute of Public Accountants and released at the same time. The Code has a comply-or-explain basis. It became effective from the 2005 fiscal year.

The Code intends to strengthen shareholders' confidence in listed companies and helps ensure the greatest possible value creation in the interests of shareholders, employees, and other stakeholders. The Code consists of a large number of separate recommendations which can be categorized into three types: issues relating to the protection of minority shareholders; issues relating to the company leadership; and issues 
relating a company's relationship with the public, external investors and creditors (International Financial Law Review).

The CGR year of Norway is treated to be 2005 when the Code becomes effective.

\section{Reference:}

The Norwegian Code of Practice for Corporate Governance

(http://www.ecgi.org/codes/documents/cg_norway_en.pdf).

Norwegian Code of Practice for Corporate Governance

(http://www.nues.no/filestore/Circular2-2006.pdf).

International Financial Law Review (http://www.iflr.com/Supplement/69164/The-IFLRGuide-to-Corporate-Governance-2004.html).

Clarke, Thomas, International Corporate Governance: A comparative approach, Routledge, ISBN 041532310x, 9780415323109, 2007.

eSTANDARDSFORUM

(http://www.estandardsforum.org/jhtml/country/Norway/sp/134/6/).

\section{Peru (2005) (Comply-or-explain Rule)}

In 2002, a committee under the leadership of the National Supervisory Commission of Companies and Securities (Comisión Nacional Supervisora de Empresas y Valores CONASEV) issued a voluntary Code of Good Corporate Governance. The year of 2005 is the first year when the Code was required to comply or explain the adherence in annual reports for listed companies.

The Code is mainly based on the Principles of the OECD (1999 version). It includes general recommendations on board organization and functions, as well as protection of minority rights. It covers the issues relating to: shareholders' rights; equal treatment of shareholders; role of stakeholders in corporate governance; disclosure and transparency of financial information; responsibilities of the board of directors; and securities market registry. 
The CGR year in Peru is treated to be 2005 when Peruvian publicly listed companies are required to document their adherence to the Code in their annual reports on a comply-orexplain basis.

\section{Reference:}

eSTANDARDSFORUM (http://www.estandardsforum.org/jhtml/country/Peru/sp/141/6/).

Principles of Code Governance for Peruvian Companies

(http://www.ecgi.org/codes/documents/code_jul2002_en.pdf).

\section{Poland (2002) (Comply-or-explain Rule)}

The Best Practice Committee was founded in May 2001 for the preparation of corporate governance principles. The Code of Best Practices in Public Companies was implemented into Warsaw Stock Exchange Rules in 2002. The Best Practices constitute a set of detailed rules of conduct addressed to both authorities of companies and members of such authorities, and to majority and minority shareholders. They have a comply-orexplain basis.

The Best Practices include: five general rules; best practices for general meetings; best practices for supervisory boards; best practices for management boards; and best practices in relation to third party institutions.

Additionally, in 2002, the Corporate Governance Code for Polish Listed Companies was issued. This Code also has a comply-or-explain basis.

The CGR year of Poland is treated to be 2002 .

\section{Reference:}

Best Practices in Public Companies in 2002

(http://www.ecgi.org/codes/documents/practices_2002.pdf).

The Corporate Governance Code for Polish Listed Companies (final proposal)

(http://www.ecgi.org/codes/documents/code_final_complete.pdf). 
eSTANDARDSFORUM (http://www.estandardsforum.org/jhtml/country/Poland/gc/143/).

\section{Singapore (2003) (Comply-or-explain Rule)}

The Code of Corporate Governance was promulgated by the Corporate Governance Committee on March 21, 2001. The Government announced its acceptance on April 4, 2001 at the OECD Third Asian Roundtable on Corporate Governance. The Code took effect in 2003. For annual general meetings held from January 1, 2003 onwards, in their annual reports, listed companies are required under the Listing Rules of the Singapore Exchange to describe their corporate governance practices with specific reference to the principles of the Code, as well as disclose and explain any deviation from any Guidance Notes of the Code. Listed companies are encouraged to comply with the code before the above deadline (Corporate Governance Committee, Report of the Committee and Code of Corporate Governance).

The Code is divided into four main sections: board matters; remuneration matters; accountability and audit; and communication with shareholders.

The CGR year of Singapore is treated to be 2003 when the Code becomes effective.

\section{Reference:}

http://www.ccdg.gov.sg/

Code of Corporate Governance (http://www.ecgi.org/codes/documents/cg_code.pdf)

Corporate Governance Committee, Report of the Committee and Code of Corporate Governance

(http://www.mas.gov.sg/resource/publications/consult_papers/corfinalrpt.pdf).

\section{South Korea (1999) (Legal Rule)}

Poor corporate governance practices was identified as one of the principle reasons for the 1997 Korean financial crisis by the IMF and World Bank. The IMF pushed the Korean government for increased accounting transparency through independent audits, and mandated consolidated financial statements, and rapid chaebol reform. Chaebol reforms 
were initiated: (1) to change the traditional characteristics of chaebol; and (2) to build an Anglo-American corporate governance system. The Korean government responded by amending the Commercial Code, which applies to all companies, and the Securities Exchange Act, which applies only to companies whose securities are floated on the Korea Stock Exchange (KSE) or traded through the Korea Securities Dealers Association Automated Quotation system in 1998. Through forcible chaebol reform by the government, accountability, transparency and financial health in the chaebol were improved.

Additionally, in 1998, the government liberalized the market for hostile M\&As and introduced policies to protect minority shareholders' rights. Accounting principles compiling with international standards were introduced in December 1998. Furthermore, the Committee on Corporate Governance was founded as a non-government body in March 1999, to develop a code of best practices, a source to guide preparations to establish proper corporate governance structure. In September 1999, the Committee adopted the Code of Best Practice for Corporate Governance. Compliance of the Code is voluntary, and there is no comply-or-explain obligation.

The CGR year of Korea is treated to be 1999, since the Commercial Code is amended in December 1998 and the effects of the reform are expected to be observed in 1999.

\section{Reference:}

Ahmadjian, Christina L. and Jaeyong Song, "Corporate Governance Reform in Japan and South Korea: Two Paths of Globalization,” Discussion paper No. 23, 2004.

Asian Corporate Governance Association (http://www.acga-asia.org).

Code of Best Practice for Corporate Governance

(http://www.ecgi.org/codes/documents/code_korea.pdf). eSTANDARDSFORUM

(http://www.estandardsforum.org/jhtml/country/South\%20Korea/sp/12/6/\#). 
Solomon, Jill, Aris Solomon and Chang-Young Park, "A Conceptual Framework for Corporate Governance Reform in South Korea," Corporate Governance an International Review, 10 (2002).

\section{Spain (2003) (Comply-or-explain Rule)}

The first Spanish Code of Best Practice was issued on February 26, 1998 (Olivencia Report, 1998). It set out recommendations on the responsibilities, structure and organization of the board of directors. However, compliance with the Code was optional rather than compulsory and the compliance rate was less successful than expected. Also, this legal reform mainly aimed at liberalizing markets and privatizing SOEs (Mallin, 2006).

Following the corporate scandals at the beginning of the twenty-first century, and the subsequent Winter Report, in 2002 the Ministry of Economy appointed a committee to issue the second code of best practice. The Aldama Committee's Report (the Spanish Transparency Act, "Ley de Transparencia," Order ECO/3722/2003) in January 2003 and the Spanish Securities and Exchange Commission (CNMV) Circular 1/2004 issued in March 2004 on the Annual Corporate Governance Report are the most relevant milestones of Spanish corporate governance system to date. They are viewed as a successful step in a transition toward more effective corporate governance in Spain. The Aldama Report's recommendations are similar to those of the Olivencia Report. They emphasized the need to regulate the information provided by the companies to the market, in particular, the need to regulate the corporate governance information that should be released by listed companies both in the Annual Corporate Governance Report and on the web page. The Aldama Report includes both voluntary and comply-or-explain regulations.

The Aldama Report coincided with a series of legislative reforms. At the end of 2002, the Law of Reform of the Financial System obliged companies to set up an audit committee composed of a majority of non-executive directors. In April 2003, the Spanish takeover law was modified. In July 2003, the Transparency Law reformed Spanish Company Law 
and established the obligation to publish a Rule of the Board of Directors and a Rule of the Shareholders' Meetings and to register such rules with the Spanish Supervisory Agency.

As a consequence of these legislative reforms, corporate transparency and governance practices have improved significantly in 2003 and 2004 (Mallin, 2006). After accounting for these regulatory events and facts, the CGR year of Spain is treated to be 2003.

\section{Reference:}

Clarke, Thomas, International Corporate Governance: A comparative approach, Routledge, ISBN 041532310x, 9780415323109, 2007.

Mallin, Christine A., "Handbook on International Corporate Governance: Country Analyses,” Edward Elgar Publishing, ISBN 1845420349, 9781845420345, 2006.

Mckean, Ashley, Corporate governance law in Spain: A vibrant transition fueled by the recent reforms of Aldama, Georgetown Journal of International Law, Fall 2003.

\section{Sweden (2005) (Comply-or-explain Rule)}

Like many other countries, Sweden suffered its own corporate scandals (e.g., the Skandia scandal $)^{11}$. In response to the business scandals, the Code Group issued the proposal for the Swedish Code of Corporate Governance in April 2004. The proposal was circulated for comments, and the final version was presented on December 16, 2004. In July 2005, the Swedish Code of Corporate Governance was enacted on a comply-or-explain basis as a supplement to the Companies Act and other legislation. It applies to all companies listed on the Nordic Exchange in Stockholm and all other listed companies whose market capitalization exceeds 3 billion SEK. The Code has been incorporated into the listing requirements of the Stockholm Stock Exchange.

\footnotetext{
${ }^{11}$ Insurance giant Skandia was rocked by a financial scandal in its home country of Sweden. Flawed auditing and a strong management unchecked by a weak board are believed by financial experts to have been at the root of the scandal. The firm paid bonuses worth three billion kronor $(\$ 396 \mathrm{~m})$ to senior managers. It has also been reported that three senior bosses renovated luxury apartments using the company's money. Its chairman Bengt Braun resigned following a damning independent investigation into Sweden's biggest corporate scandal in 70 years.
} 
The Code serves as a guideline for Swedish companies. It aims to improve the governance of Swedish companies, primarily to ensure that companies are run in the best interests of the owners. Another aim is to enhance understanding and confidence in Swedish corporate governance (Clarke, 2007). The Swedish code is part of the European tradition that has grown from developments in the UK in the early 1990s, but is also influenced by the OECD and the EU, as well as corporate governance codes of other countries. Recent initiatives from the EU have played a major part in the structure of the Swedish code. The Code covers five key areas: (1) shareholders' meetings; (2) appointment of board directors and auditor; (3) board of directors; (4) executive management; and (5) corporate governance reporting.

Additionally, there are two other corporate governance codes in Sweden. In 2001 the Swedish Shareholders' Association issued the Guidelines for Better Control and Transparency for owners of companies quoted on the Swedish stock market. In 2003, the Swedish Industry and Commerce Stock Exchange Committee (Näringslivets Börskommitté, or NBK) issued rules. However, the compliance results to the 2001 Guidelines for owners of companies quoted on the Swedish stock market are not very encouraging. The NBK is a mandatory regulation, but it focuses only on takeover related regulations. Therefore, the CGR year of Sweden is treated to be 2005 when the Swedish Code of Corporate Governance is enacted.

\section{Reference:}

Clarke, Thomas, International Corporate Governance: A comparative approach, Routledge, ISBN 041532310x, 9780415323109, 2007.

eSTANDARDSFORUM

(http://www.estandardsforum.org/jhtml/country/Sweden/sp/168/6/). http://www.ecgi.org/codes/documents/nbk_recommendations.pdf.

The Swedish Code of Corporate Governance (http://www.bolagsstyrningskollegiet.se/en/0000004.asp). 


\section{Switzerland (2002) (Comply-or-explain Rule)}

The introduction of the two new sets of corporate governance rules in 2002 marked a milestone in the development of corporate governance system in Switzerland (Global Corporate Governance Guide 2004).

The Directive on Information relating to Corporate Governance, issued by the SWX Swiss Exchange, aims to enhance corporate transparency. It is intended to encourage publicly listed companies to make certain key information relating to corporate governance available to investors in an appropriate form. It requires Swiss listed issuers to disclose in their annual reports important information on the management and control mechanisms at the highest corporate level. Information on remuneration is compulsory, and other broad categories of information (e.g., group and capital structure, board of directors, auditors, shareholder participation rights, change of control or defence measures, and information policy) is required to be dealt with the comply-or-explain principle. It came into force on July 1, 2002 and applies to all annual reports of listed companies for fiscal years beginning on January 1, 2002. The SWX directive has been viewed to be an efficient tool to increase the transparency of the corporate governance mechanisms of Swiss companies in general.

The Swiss Code of Best Practice for Corporate Governance was unanimously approved on March 25, 2002 by the Board of Directors of Economies Cuisse on the unanimous recommendation of the Panel of Experts. It sets corporate governance standards which have the character of non-binding recommendations. The code primarily addresses Swiss publicly listed companies, but also serves as a guideline for non-listed Swiss companies and organisations of economic significance.

The year of 2002 thus is treated to be the CGR year of Switzerland.

\section{Reference:}

Directive on Information Relating to Corporate Governance (Corporate Governance Directive, DCG) (http://www.ecgi.org/codes/documents/rlcg_02_en.pdf). 
Global Corporate Governance Guide 2004

(http://www.globalcorporategovernance.com/).

Recent Corporate Governance Reforms in Switzerland

(http://www2.eycom.ch/library/items/200603_cogo/en.pdf).

Swiss Code of Best Practice for Corporate Governance

(http://www.ecgi.org/codes/documents/swisscodeofbestpractice_english.pdf).

\section{Taiwan (2002) (Legal Rule)}

Following the 1997 Asian financial crisis, Taiwan initiated an overall reform of its corporate governance system. According to the 2006 conference report "Corporate Governance and Taiwan's Capital Markets," these reforms were later accompanied by improvements in corporate governance starting in 2002. These reforms focused on greater independence for the board of directors, audit committees, and supervisory commissions (eSTANDARDSFORUM).

The amendment of the Corporate Law of Taiwan was promulgated on July 9, 2001, and became effective on November 1, 2001. The Company Law sets out the legal position with which Taiwanese companies have to comply. It formally establishes a legal foundation for a corporate governance system in Taiwan. Some studies on 2001 Company Law suggest a positive impact of it on investor protection.

In addition, Taiwan Stock Exchange (TSE) and Taiwan's GreTai Securities Market (GTSM) amended their listing rules to require all companies seeking IPO after 2002 to have at least two independent directors and one independent supervisor. The SFC mandated the definition of qualifications for independent directors and independent supervisors on April 4, 2003. To provide the legal basis for protecting investors, SFC enacted the Securities Investors and Futures Traders Protection Law. It was passed by the parliament in July 2002 and enacted on January 1, 2003. Furthermore, Taiwan Corporate Governance Best-Practice Principles were issued in 2002 by the TSE and GTSM. But the Principles are not mandatory. 
The year of 2002 is treated to be the CGR year of Taiwan, because this series of intensive regulation regimes took place around 2002 and the Company Law of Taiwan became effective on November 1, 2001, close to the end of 2001.

\section{Reference:}

Asian Corporate Governance Association (http://www.acga-

asia.org/content.cfm?SITE_CONTENT_TYPE_ID=12\&COUNTRY_ID=282).

eSTANDARDSFORUM

(http://www.estandardsforum.org/jhtml/country/Taiwan/sp/191/6/).

Solomon, Jill F., Shih Wei Lin, Simon D. Norton, and Aris Solomon, "Corporate Governance in Taiwan: Empirical evidence from Taiwanese company directors, Corporate governance: An international review, 11 (2003), PP. 235-248.

Taiwan Corporate Governance Best-Practice Principles 2002

(http://www.ecgi.org/codes/documents/taiwan_cg_principles.pdf).

Wisconsin International Corporate Governance Initiative, "Report on the Conference on Corporate Governance and Taiwan's Capital Markets," April 2006. Available from University of Wisconsin Law School website. Accessed on March 26, 2008. (WICGI 2006) (http://law.wisc.edu/webshare/02J7/corporate-governance-conference-report.pdf).

\section{Thailand (2007) (Comply-or-explain Rules)}

After the 1997 Asian financial crisis, Thailand conducted several legislative activities issuing the Stock Exchange of Thailand's (SET) Code of Best Practice for Directors of Listed Companies in 1999 and the 2002 Code of Best Practice for Directors of Listed Companies. However, they are simply guidelines, not legal requirements. Also, they focus only on the board of directors.

The Principles of Good Corporate Governance, published in March 2006, is an updated version of the 15 principles announced in March 2002. The new document follows closely the five key OECD corporate governance principles and adopts recommendations made by the World Bank. It has a comply-or-explain basis. The new Code is presented in 
five categories: shareholder rights; equitable treatment of shareholders; and the role of stakeholders; disclosure and transparency; responsibilities of the board. One of the most interesting aspects of the new code concerns the conduct of shareholder meetings. In an effort to encourage companies to adopt clear procedures for allowing minority shareholders to propose agenda items for annual meetings, the code lays down a detailed "best practices guideline" on the subject (Asian Corporate Governance Association).

Companies are required to disclose the extent of their compliance with the code's principles in their 2007 annual statements and annual reports (eSTANDARDSFORUM). The year of 2007 is treated to be the CGR year of Thailand.

\section{Reference:}

Asian Corporate Governance Association (http://www.acga-asia.org).

Clarke, Thomas, International Corporate Governance: A comparative approach, Routledge, ISBN 041532310x, 9780415323109, 2007.

Code of Best Practice for Directors of Listed Companies

(http://www.ecgi.org/codes/documents/thailand_code_oct1999.pdf).

eSTANDARDSFORUM

(http://www.estandardsforum.org/jhtml/country/Thailand/sp/173/6/).

The Principles of Good Corporate Governance for Listed Companies

(http://www.ecgi.org/codes/documents/cg_principles_thailand_2006_en.pdf).

The SET Code of Best Practice for Directors of Listed Companies

(http://www.ecgi.org/codes/documents/ror_26_00.pdf).

The Stock Exchange of Thailand (http://www.set.or.th/en/index.html).

\section{UK (2003) (Comply-or-explain Rule)}

In response to the collapse of Enron and WorldCom, the UK introduced the new Combined Code on Corporate Governance. The Code was issued in July, 2003 by the Financial Reporting Council, and was put into effect on November 1, 2003. The Code applies to publicly listed companies, on the comply-or-explain approach. The issuance of this Code is viewed as the most important recent development of corporate governance in 
the UK. The corporate governance system has been certainly improved, and the UK's Combined Code is effective and widely admired. (Global Corporate Governance Guide 2004; Hodge, 2007)

The Combined Code is also in the wake of the Higgs Review. The Higgs Review was published in January, 2003. In April 2002 the Secretary of State, Patricia Hewitt, and the Chancellor, Gordon Brown, appointed Derek Higgs to lead an independent review of the role and effectiveness of non-executive directors. The report by Higgs includes guidance for non-executive directors and the chairman and a proposal for a revised combined code. The proposal contains a number of recommendations relating to the structure of the board; the role and other commitments of the chair; the role of the non-executive director; the recruitment and appointment procedures to the board; professional development of directors; board tenure and time commitment; remuneration; resignation procedures; audit and remuneration committees; board liability; and relationships with shareholders.

This Code replaced the old Combined Code introduced by the Hampel Committee on Corporate Governance in June 1998. It aims to enhance board effectiveness and to improve investor confidence by raising standards of corporate governance. The key sections of the Code include: 50\% independent non-executive directors within the board (chairman excluded); separation of the roles of chairman and chief executive officer; new rules on independence of board directors; formal procedures for the appointment of new directors; provisions for more relevant management information to directors; training and performance evaluation of boards, committees and directors; the role of audit committee and auditors scoped out; and sanctions.

The CGR year of the UK is treated to be 2003 when the new Combined Code on Corporate Governance becomes effective.

\section{Reference:}

Clarke, Thomas, International Corporate Governance: A comparative approach, Routledge, ISBN 041532310x, 9780415323109, 2007. 
The Cobmined Code on Corporate Governance, July 2003

(http://www.ecgi.org/codes/documents/combined_code_final.pdf).

Global Corporate Governance Guide 2004

(http://www.globalcorporategovernance.com/).

eSTANDARDSFORUM

(http://www.estandardsforum.org/jhtml/country/United\%20Kingdom/sp/18/6/).

Hodge, Chris, "Review of the impact of the Combined Code", Corporate Governance

Unit, Financial Reporting Council (2007)

(http://www.frc.org.uk/documents/pagemanager/frc/combined_code_responses/Hanson\% 20Green.pdf).

Jones, Ian and Michael Pollitt, "Understanding how issues in corporate governance develop: Cadbury report to Higgs Review," Centre for Business Research Working Paper, 2003.

Review of the Role and Effectiveness of Non-executive Directors, January 2003

(http://www.ecgi.org/codes/documents/higgsreport.pdf).

\section{U.S. (2004) (Legal Rule)}

The Sarbanes-Oxley Act of 2002 is also known as the Public Company Accounting Reform and Investor Protection Act of 2002. It is a US federal law enacted on July 30, 2002 in response to a number of major corporate and accounting scandals (e.g., Enron, Tyco International, Adelphia, Peregrine Systems, and WorldCom). President George W. Bush signed it into law, stating it included "the most far-reaching reforms of American business practices since the time of Franklin D. Roosevelt."

The legislation establishes new standards for all US public company boards, management, and public accounting firms. The Act covers issues such as auditor independence, corporate governance, internal controls, and enhanced financial disclosure. It contains 11 sections: public company accounting oversight board (PCAOB); auditor independence; corporate responsibility; enhanced financial disclosures; analyst conflicts of interest; commission resources and authority; studies and reports; corporate and criminal fraud 
accountability; white collar crime penalty enhancement; corporate tax returns; and corporate fraud accountability.

The CGR year of the U.S. is treated to be 2004 when most firms are required to subject to the new rules.

\section{Reference:}

\section{eSTANDARDSFORUM}

(http://www.estandardsforum.org/jhtml/country/United\%20States/sp/19/6/).

Wikipedia (http://en.wikipedia.org/wiki/Sarbanes-Oxley_Act). 